\title{
Synthesis and identification of metabolite biomarkers of 25C-NBOMe and 25I-NBOMe
}

Xiongyu Wu, Caroline Eriksson, Ariane Wohlfarth, J akob Wallgren, Robert

Kronstrand, Martin J osefsson, J ohan Dahlén and Peter Konradsson

The self-archived postprint version of this journal article is available at Linköping University Institutional Repository (DiVA):

http:// urn.kb.se/ resolve?urn=urn:nbn:se:liu:diva- 142827

N.B.: When citing this work, cite the original publication.

Wu, X., Eriksson, C., Wohlfarth, A., Wallgren, J ., Kronstrand, R., J osefsson, M., Dahlén, J .,

Konradsson, P., (2017), Synthesis and identification of metabolite biomarkers of 25C-NBOMe and 25I-

NBOMe, Tetrahedron, 73(45), 6393-6400. https:// doi.org/ 10.1016/j.tet.2017.09.024

Original publication available at:

https:// doi.org/ 10.1016/j.tet.2017.09.024

Copyright: Elsevier

http:// www.elsevier.com/

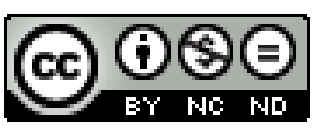




\title{
Synthesis and Identification of Metabolite Biomarkers of 25C-NBOMe and 25I- NBOMe
}

\author{
Xiongyu $\mathrm{Wu}^{\mathrm{a}}{ }^{*}$, Caroline Eriksson ${ }^{\mathrm{a}}$, Ariane Wohlfarth ${ }^{\mathrm{b}, \mathrm{c}}$, Jakob Wallgren ${ }^{\mathrm{a}}$, Robert Kronstrand ${ }^{\mathrm{b}, \mathrm{c}}$, Martin \\ Josefsson ${ }^{\mathrm{b}, \mathrm{c}}$, Johan Dahlén ${ }^{\mathrm{a}}$, Peter Konradsson ${ }^{\mathrm{a}}$ \\ ${ }^{a}$ Department of Physics, Chemistry and Biology, Linköping University, Sweden \\ ${ }^{b}$ Department of Forensic Genetics and Forensic Toxicology, National Board of Forensic Medicine, Sweden \\ ${ }^{c}$ Division of Drug Research, Department of Medical and Health Sciences, Faculty of Health Sciences, Linköping University, Sweden
}

\section{ARTICLE INFO ABSTRACT}

\section{Article history:}

Received

Received in revised form

Accepted

Available online

\section{Keywords:}

Biomarker

25C-NBOMe

25I-NBOMe

Metabolite

Urinary detection
Synthetic routes have been developed for synthesis of potential metabolites of 25C-NBOMe and 25I-NBOMe. Nine potential metabolites have been synthesized, among which compounds 8 and 20a could be used as metabolite biomarkers of 25C-NBOMe and 20b of 25I-NBOMe in urinary detection at forensic laboratories to prove intake.

\section{Introduction}

It is estimated that a total of 246 million people, or 1 out of 20 people between the ages of 15 and 64 years, used an illicit drug in 2014 according to the World Drug Report 2016. Although drug abuse may lead to many health and social problems, ${ }^{1}$ new psychoactive substances (NPS) that are produced by clandestine laboratories and purchased via the internet head shops, keep being pumped into the market with 66 new psychoactive substances firstly reported to the EU early warning system in $2017 .^{2}$

The NBOMes (N-Benzyl-oxy-methyl derivatives of 2C phenylethylamines), a new group of NPS, have strong hallucinogenic effects and have been reportedly sold as a legal alternative to lysergic acid diethylamide (LSD). More than 39 NBOMes and analogues have been reported. ${ }^{3-4}$ The most commonly abused NBOMes are 25I-NBOMe, 25C-NBOMe and 25B-NBOMe (Fig. 1), which are now scheduled as controlled substances in many countries. Ingestion of these substances can cause tachycardia, agitation, hallucination, hypertension, confusion and mydriasis. ${ }^{5,6}$ Cases of fatal intoxication associated with the use of NBOMes have been reported around the world, e.g. in the US, Europe, and Australia. ${ }^{6-8}$

It can be challenging to detect NPS because the parent drugs are not always found in urine specimens. Metabolites can be a more suitable target and can also extend the time window of detection.

\footnotetext{
*Corresponding author. E-mail address: xiongyu.wu@liu.se
}

Therefore, metabolite identification studies to determine NPS biomarkers are important. There are only a few reports on NBOMe metabolism although fatal intoxication cases caused by using NBOMes have been reported in several countries. Studies on the metabolism of 25I-NBOMe and 25B-NBOMe using LC-HR-MS etc. analytical methods have been carried out by Caspar and Boumrah in 2015. ${ }^{9-10}$ In the same year, Poklis et al. reported the identification of metabolite biomarkers of 25I-NBOMe as well as the synthesis of two major metabolites with 8 and 9 steps respectively. ${ }^{11}$ With synthetic reference standards, the metabolites with mono-demethylation of the 2,5-dimethoxyphenyl ring can now be distinguished. Since the synthetic route is long, there is need for optimization or identification of other metabolite biomarkers, which could be synthesized in fewer steps.

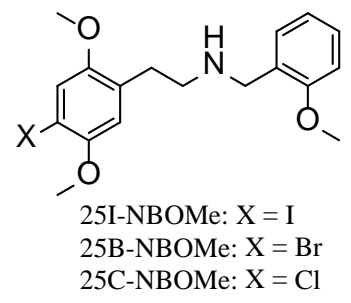

Figure 1. Structures of 25I-NBOMe, 25B-NBOMe and 25C-NBOMe

25C-NBOMe is one of the most abused NBOMes; to the best of our knowledge, there are no reports on the synthesis of its metabolite biomarkers. In collaboration with the National Board 
of Forensic Medicine of Sweden we synthesized several potential metabolites of 25C-NBOMe and 25I-NBOMe for comparison.

\section{Results and discussion}

Aldehyde $\mathbf{2}$ is commercially available. It can also be synthesized from compound 1 using MeI under basic conditions. ${ }^{12}$ The methylation is selective, which might be due to the acidic difference of the two phenol groups. The yield was moderate due to incomplete conversion. Henry reaction between compound 2 and nitromethane gave $\mathbf{3}$ in high yield. When a higher amount of nitromethane was used with starting material of $\mathbf{9}$, a lower yield was obtained and dialkylation side product was increased. The reduction of $\mathbf{3}$ to $\mathbf{4}$ with $\mathrm{LiAlH}_{4}$ was straightforward but the workup was problematic and led to lower yield than expected. Protection of $\mathbf{4}$ using trifluoroacetic anhydride gave 5, which could undergo chlorination with NCS without protection of the phenol. The chlorination selectively occurred at the ortho position of phenol to give compound $\mathbf{6}$ as the major product. After deprotection and reductive amination, compound $\mathbf{8}$ was obtained. The yield was low. Full conversion was not achieved with $\mathrm{NaCNBH}_{3}$ although an excess amount of reagent was added. $\mathrm{NaBH}_{4}$ was then added. The lower yield might be caused by the poor quality of $\mathrm{NaCNBH}_{3}$. The synthetic route of $\mathbf{8}$ was two steps shorter than its metabolite analogue of 25I-NBOMe, which was reported by Poklis et al. ${ }^{11}$ The overall yield might be increased with reagents of better quality (Scheme 1).

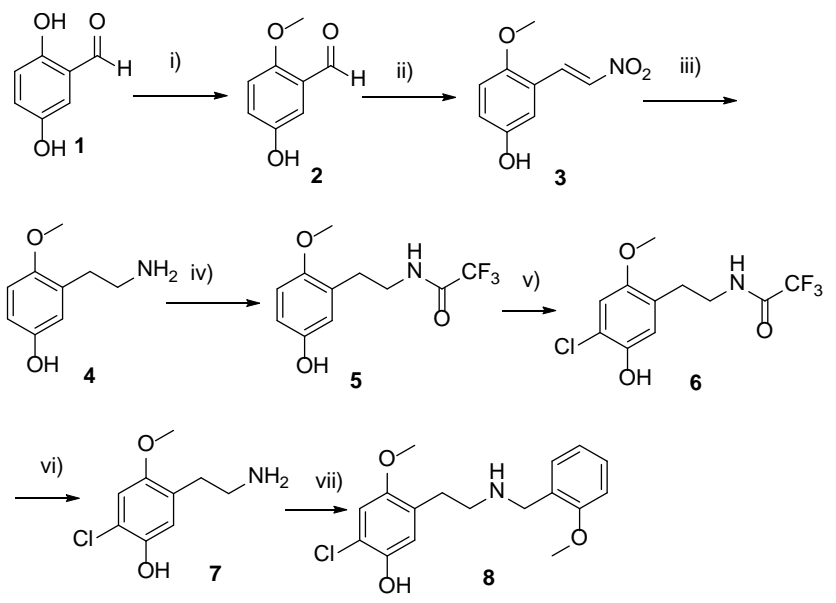

Scheme 1. i) MeI, $\mathrm{K}_{2} \mathrm{CO}_{3}$, DMF, 57\%; ii) $\mathrm{CH}_{3} \mathrm{NO}_{2}$ (14 equiv.), $\mathrm{NH}_{4} \mathrm{OAc}$ (0.65 equiv.), AcOH, 94\%; iii) $\mathrm{LiAlH}_{4}$, THF, 59\%; iv) TFAA, DCM, 52\%; v) NCS, acetonitrile, $75^{\circ} \mathrm{C}, 30 \mathrm{~min}, 73 \%$; vi) $5 \% \mathrm{NaOH}$, EtOH, rt, vii) 2methoxybenzaldehyde, $\mathrm{NaCNBH}_{3}$ and $\mathrm{NaBH}_{4}$, EtOH, rt, $26 \%$.

Following a similar procedure 15a, another potential metabolite of 25C-NBOMe, was synthesized (Scheme 2). The difference was that the phenol had to be protected with an acyl group to increase the selectivity of chlorination at the ortho position of the methoxy group. Instead of protecting with an acyl group, excess amount of trifluoroacetic anhydride was also tested to give a di-trifluoroacyl protected intermediate to reduce one step, unfortunately it failed. Both protective groups could be removed under basic conditions in the same procedure. A similar metabolite of 25I-NBOMe, compound $\mathbf{1 5 b}$, was synthesized using a similar procedure (Scheme 2). Compared to the synthesis reported in the literature, our procedure required one step less and replaced 2-bromo propane for protection and $\mathrm{BCl}_{3}$ for deprotection by more common reagents.

Both metabolites of 25C-NBOMe, compound 8 and 15a, were used as reference standards in the analysis of two authentic forensic urine specimens (Fig. 2A). It was found that compound 8 , 5'-desmethyl-25C-NBOMe, was more abundant than 15a, 2'desmethyl-25C-NBOMe, suggesting that compound $\mathbf{8}$ is a good metabolite biomarker of 25C-NBOMe. Moreover, it was found that 15b, 2'-desmethyl-25I-NBOMe, was not a good metabolite biomarker for analysis of intake of 25I-NBOMe either (Fig. 2C). ${ }^{13}$ Although the synthesis of $\mathbf{8}$ and $\mathbf{1 5}$ was carried out successfully with improvement, the synthetic route was still long. However other metabolites that can be synthesized with shorter synthetic routes could be identified and used as biomarkers too. 25B/I/CNBOMes were metabolized by O-demethylation, O-didemethylation and hydroxylation. ${ }^{11,13}$ Metabolites with a hydroxyl group on the benzyl ring of 25C/I-NBOMe were then synthesized.

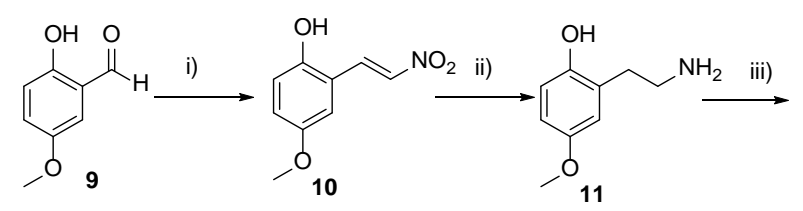

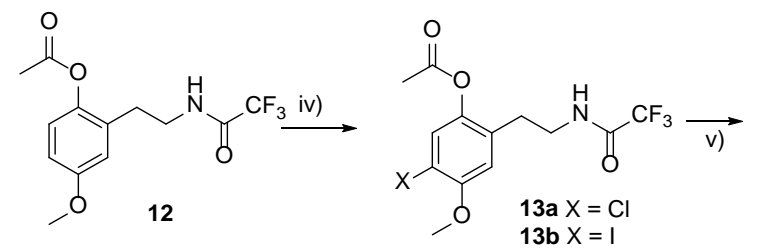<smiles>[X]c1cc(O)c(CCN)cc1OC</smiles>

Scheme 2. i) $\mathrm{CH}_{3} \mathrm{NO}_{2}$ (30 equiv.), $\mathrm{NH}_{4} \mathrm{OAc}$ (1 equiv.), $\mathrm{AcOH}, 120^{\circ} \mathrm{C}, 70$ min, 68\%; ii) $\mathrm{LiAlH}_{4}$, THF, $65^{\circ} \mathrm{C}$, 4h, 71\%; iii) a) TFAA, TEA, THF, rt; b) acetyl chloride, TEA, $\mathrm{CHCl}_{3}$, rt, 51\%; iv) 13a: NCS, acetonitrile, rt, $65 \%$; 13b: NIS, conc. $\mathrm{H}_{2} \mathrm{SO}_{4}$, acetonitrile, rt, $65 \%$; v) $5 \% \mathrm{NaOH}$, EtOH, rt, $100 \%$ for both 14a and 14b; vi) 2-methoxybenzaldehyde, $\mathrm{NaCNBH}_{3}$, DCE, rt, $36 \%$ and $35 \%$ for $\mathbf{1 5 a}$ and $\mathbf{1 5 b}$, respectively.

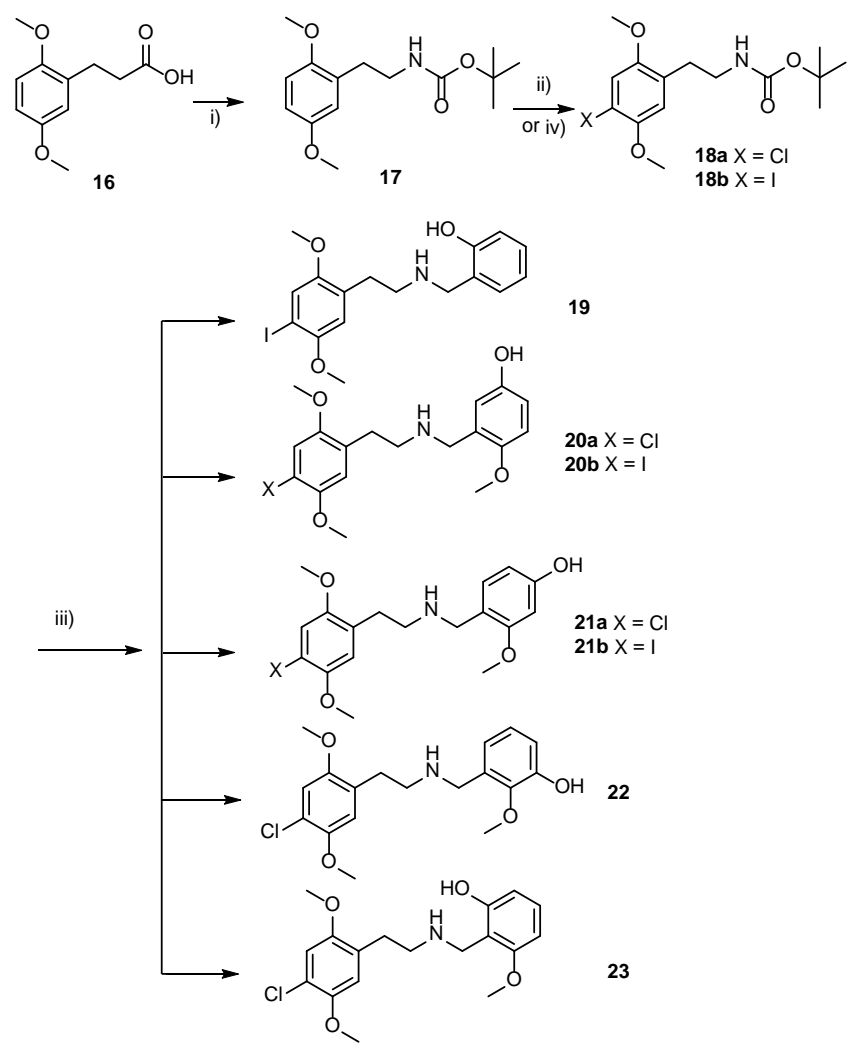

Scheme 3. i) $\mathrm{NaN}_{3}, \mathrm{Bu}_{4} \mathrm{NBr}, \mathrm{Zn}(\mathrm{OTf})_{2}$, $\mathrm{Boc}_{2} \mathrm{O}$, THF, 72\%; ii) 18a: NCS, acetonitrile, MW, $75{ }^{\circ} \mathrm{C}, 84 \%$; 18b: NIS, AcOH, rt, 65\%; iii) a) TFA, DCM; b) 21b: $\mathrm{NaBH}_{4}, \mathrm{EtOH}, 49 \%$; iv) a) NCS, acetonitrile, MW, $75{ }^{\circ} \mathrm{C}$; b) TFA, DCM, rt; c) aldehyde, $\mathrm{NaBH}_{4}$ or $\mathrm{Na}(\mathrm{OAc})_{3} \mathrm{BH}$ or $\mathrm{NaCNBH}_{3}$, overall yield from 17 or 18b: 20a: 76\%; 20b: 50\%; 21a: $60 \%$; 22: 27\%; 23: $56 \%$. 

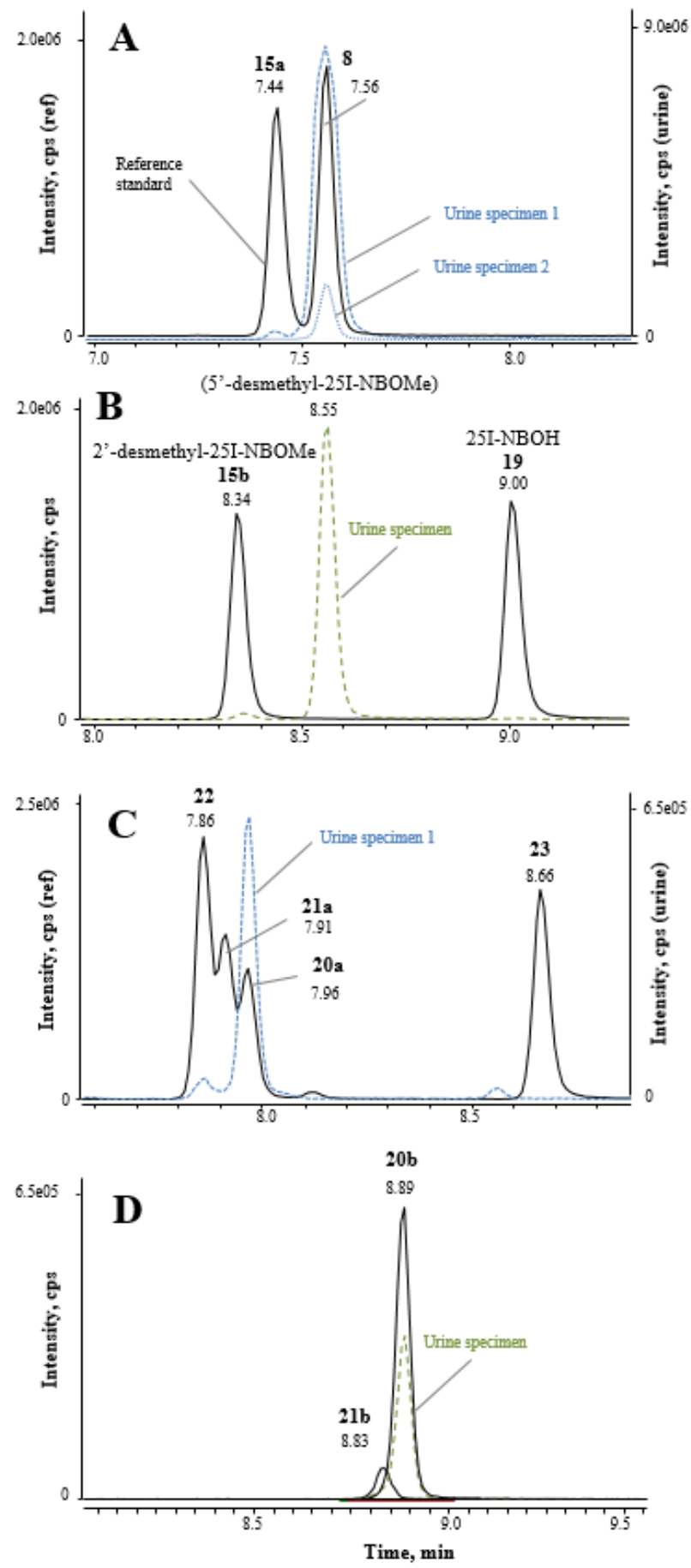

Figure 2. Analysis of synthesized potential metabolites of NBOMes (solid line) and authentic humman urine cases (dashed line) using LC-QTOF with an ACE Excel 2 C18-AR column and an extended gradient.

The position of the hydroxyl group of a major metabolite of NBOMes at the benzyl ring was controversial in literature. ${ }^{13,15-17}$ Therefore, it is imperative to have all four possible metabolites to address the problem. Here we have synthesized all of them, 20a, 21a, 22 and $\mathbf{2 3}$ (Scheme 3).

Compound 17 was synthesized using a Curtius rearrangement from 16 with $\mathrm{Boc}_{2} \mathrm{O} / \mathrm{NaN}_{3}$ under catalysis of $\mathrm{Zn}(\mathrm{TfO})_{2} .{ }^{14}$ The amino group was protected at the same time. The resulting product 17 was then halogenated, deprotected using TFA, followed by reductive amination to give compounds $\mathbf{2 0 - 2 3}$, with hydroxylation at $6,5,4$ or 3 position of the benzyl ring of NBOMe, respectively. Compound 19 was also synthesized for comparison with metabolite 15b. It was found that it is not a proper metabolite biomarker (Fig. 2B). Therefore, we refrained from synthesizing its chloro analogue. The synthesis of 20-23 was straightforward (Scheme 3). The rearrangement worked but was sensitive. The yield of 17 varied from $45-72 \%$ under similar conditions by different chemists. Chlorination of $\mathbf{1 7}$ gave full conversion at $\mathbf{7 5}$ ${ }^{\circ} \mathrm{C}$ using either MW irradiation or conventional heating. The selectivity was good, but product with chloro group at position 6 was still found. Compound 21a was not stable and decomposed during concentration under heating at $50{ }^{\circ} \mathrm{C}$ after LC purification. The fractions from preparative LC turned red and the bond between the amine group and the benzyl ring was broken to give 2-(4-chloro-2,5-dimethoxyphenyl)ethan-1-amine according to LC-MS. Its stability was much better at room temperature. Freezedrying was then used for removing solvent. It was found that compound 21b was not stable either and gave a similar side product together with another $N, N$-dibenzylation side product under heating after LC preparation. The stabilities of 20a, 22 and 23 were better.

After analysis of the human urine samples and comparison with these references, it was found that compound 20a was the correct mono-hydroxy metabolite of 25C-NBOMe and can be used as another suitable metabolite biomarker (Fig. 2C). The result was consistent with the metabolite study of 25B-NBOMe by Kristersen et al. ${ }^{16}$ Interestingly, Nielsen et al. reported that the 4-hydroxy metabolite, compound 21b, was identified as one of the major metabolites of 25I-NBOMe using human liver microsomes. In the same paper, the authors also reported that, instead of the 4-hydroxy metabolite, the 5-hydroxy metabolite at the benzyl ring was the major mono-hydroxy metabolite of 25I-NBOH, which is an analogue of 25I-NBOMe. ${ }^{17}$ During our study it was found that the four metabolites of 25C-NBOMe had very close retention times and required optimized conditions to improve separation. This may be also true for 25I-NBOMe. Compound 20b was then synthesized using a similar method (Scheme 3). It was found that instead of 21b, compound 20b was more likely to be the major mono-hydroxy metabolite of 25I-NBOMe in authentic human urine sample in our analysis (Fig. 2D).

\section{Conclusion}

Straightforward synthetic routes have been developed for the synthesis of potential metabolites of 25C-NBOMe and 25INBOMe. The yield might be improved if further optimization is carried out. Analysis of authentic urine species and human hepatocyte samples showed that 5'-desmethyl-25C-NBOMe (compound 8) and 5-OH-25C-NBOMe (compound 20a) are two metabolite biomarkers, which can be used as targets in urine analysis for 25C-NBOMe. Further study on the metabolites of 25INBOMe suggested that 5-OH-25I-NBOMe (20b), not 4-OH-25INBOMe (21b), was the major mono-hydroxy metabolite of 25INBOMe in our human urine specimen. All the three most commonly abused NBOMes, 25I/C/B-NBOMe, showed similar metabolites suggesting that other NBOMes might follow a similar metabolic pattern. Therefore, after considering the synthetic route, we found that the 5-OH-NBOMe metabolite has a potential to be developed as a general metabolite biomarker for detection of NBOMe intake from human urine.

\section{Experimental section}

\subsection{General information}

TLC was performed using $0.25 \mathrm{~mm}$ precoated silica-gel plates (Merck $60 \mathrm{~F}_{254}$ ), detection by UV-abs at $254 \mathrm{~nm} .{ }^{1} \mathrm{H}$ and ${ }^{13} \mathrm{C}-\mathrm{NMR}$ spectra were recorded on a Varian Mercury $300 \mathrm{MHz}$ instrument $\left(25^{\circ} \mathrm{C}\right.$ in $\mathrm{CDCl}_{3}$ or methanol-d $\mathrm{d}_{4}$ ). HPLC-MS was performed on a Waters system (Column: XSELECT Phenyl-Hexyl, $5 \mu \mathrm{m}, 250 \mathrm{x}$ $19 \mathrm{~mm}$ and Waters X-Bridge C-18 $3.5 \mu \mathrm{m}, 50 \times 4.6 \mathrm{~mm}$ ) for preparative and analytical experiments respectively; Mobile 
phase: organic phase: acetonitrile:water 90:10, with $10 \mathrm{mM}$ $\mathrm{NH}_{4} \mathrm{OAc}$; water phase: acetonitrile:water 5:95, with $10 \mathrm{mM}$ $\mathrm{NH}_{4}$ OAc. Flash chromatography was performed using the following silica gel: High purity grade (Merck Grade 9385), pore size $60 \AA$, 230-240 mesh particle size. The results of the highresolution mass measurements using LC-QTOF-MS by National Board of Forensic Medicine, Sweden, can be found in the experimental.

\subsection{Synthesis}

\subsubsection{5-hydroxy-2-methoxybenzaldehyde (2)}

A mixture of 2,5-dihydroxybenzaldehyde $(1 \mathrm{~g}, 7.24 \mathrm{mmol})$ and $\mathrm{K}_{2} \mathrm{CO}_{3}$ (1 g, $\left.7.24 \mathrm{mmol}\right)$ was dissolved in DMF $(10 \mathrm{~mL})$ and stirred at room temperature for 30 min before methyl iodide (0.679 $\mathrm{mL}, 10.9 \mathrm{mmol}$ ) was added. The reaction mixture was stirred at room temperature overnight. The solvent was evaporated in vacuum and the crude was purified using flash-column chromatography (n-heptane/EtOAc 2:1) to gain compound $2^{12}$ (621 mg, 57\% yield) as a yellow solid. ${ }^{1} \mathrm{H}-\mathrm{NMR}(300 \mathrm{MHz}$, $\left.\mathrm{CDCl}_{3}\right) \delta 10.33(\mathrm{~s}, 1 \mathrm{H}), 7.30(\mathrm{~d}, J=3.2 \mathrm{~Hz}, 1 \mathrm{H}), 7.10$ (dd, $J=9.0$, $3.2 \mathrm{~Hz}, 1 \mathrm{H}), 6.84$ (d, $J=8.9 \mathrm{~Hz}, 1 \mathrm{H}), 6.70$ (broad s, 1H), 3.84 (s, 3H). ${ }^{13} \mathrm{C}-\mathrm{NMR}\left(75 \mathrm{MHz}, \mathrm{CDCl}_{3}\right) \delta 190.6,156.6,150.2,125.0$, 124.1, 113.9, 113.5, 56.2.

\subsection{2 (E)-4-methoxy-3-(2-nitrovinyl)phenol (3)}

A mixture of compound 2 (303 mg, $1.99 \mathrm{mmol}$ ), nitromethane (1.5 mL, $27.7 \mathrm{mmol}$ ) and ammonium acetate (99.5 mg, $1.29 \mathrm{mmol})$ in $\mathrm{AcOH}(6.15 \mathrm{~mL})$ in a microwave vial was irradiated under MW at $120{ }^{\circ} \mathrm{C}$ for $20 \mathrm{~min}$. Water was added $(5 \mathrm{~mL})$ and the reaction mixture was extracted using DCM (3 x $15 \mathrm{~mL})$ and evaporated in vacuum to gain compound 3 (367 $\mathrm{mg}, 94 \%$ yield) as an orange solid. ${ }^{1} \mathrm{H}-\mathrm{NMR}(300 \mathrm{MHz}, \mathrm{MeOD}) \delta 8.11(\mathrm{~d}, J=13.6 \mathrm{~Hz}, 1 \mathrm{H})$, 7.87 (d, $J=13.6 \mathrm{~Hz}, 1 \mathrm{H}), 6.98-6.95$ (m, 1H), 6.95-6.93 (m, 2H), 3.88 (s, 3H). ${ }^{13} \mathrm{C}-\mathrm{NMR}$ (75 MHz, MeOD) $\delta$ 154.7, 152.6, 139.3, 136.1, 121.8, 120.8, 118.1, 114.0, 56.8.

\subsubsection{3-(2-aminoethyl)-4-methoxyphenol phenol (4)}

Compound 3 (385 mg, $1.97 \mathrm{mmol}$ ) was dissolved in THF (20 $\mathrm{mL}$ ) and cooled to $0{ }^{\circ} \mathrm{C}$. $\mathrm{LiAlH}_{4}$ (7.9 mL, $1 \mathrm{M}$ in THF solution) was added and the reaction mixture was left to stir under nitrogen gas flow at $65{ }^{\circ} \mathrm{C}$ for $4 \mathrm{~h}$. Cold water was added to the reaction along with $15 \% \mathrm{NaOH}$ (aq.) in excess and some additional THF. The solution was vacuum filtered and the filtrate was evaporated in vacuum and pre-absorbed on to silica gel before purification using flash-column chromatography (DCM/MeOH/Et ${ }_{3} \mathrm{~N}$ 90:10:1) to gain compound $\mathbf{4}^{18}$ (194 mg, 59\% yield). ${ }^{1} \mathrm{H}-\mathrm{NMR}$ (300 MHz, MeOD) $\delta$ 6.78-6.71 (m, 1H), 6.65-6.54 (m, 2H), 3.73 (s, 3H), 2.912.74 (m, 2H), 2.69 (t, $J=6.6 \mathrm{~Hz}, 2 \mathrm{H}) .{ }^{13} \mathrm{C}-\mathrm{NMR}$ (75 MHz, MeOD) $\delta$ 151.0, 150.9, 128.5, 117.2, 113.1, 111.5, 55.0, 41.3, 33.4.

\subsubsection{2,2,2-trifluoro-N-(5-hydroxy-2-methoxyphenethyl) acetamide (5)}

Compound 4 (194 mg, $1.16 \mathrm{mmol}$ ) was dissolved in THF (4 mL) and trifluoroacetic anhydride $(193 \mu \mathrm{L}, 1.39 \mathrm{mmol})$ and $\mathrm{Et}_{3} \mathrm{~N}$ (194 $\mu \mathrm{L}, 1.39 \mathrm{mmol}$ ) was added to the solution. The reaction mixture was stirred at room temperature overnight. The solvent was evaporated in vacuum, water was added to the crude and then extracted using DCM (3 x $15 \mathrm{~mL}$ ). The crude was purified using flash-column chromatography (n-heptane/EtOAc 2:1) to gain compound 5 (158 mg, 52\% yield). ${ }^{1} \mathrm{H}-\mathrm{NMR}$ (300 MHz, $\mathrm{CDCl}_{3}$ ) $\delta$ 7.46 (broad s, 1H), 6.78-6.69 (m, 2H), 6.65 (d, $J=2.2 \mathrm{~Hz}, 1 \mathrm{H}$ ),
3.78 (s, 3H), 3.57-3.44 (m, 2H), 2.86-2.77 (m, 2H). ${ }^{13} \mathrm{C}-\mathrm{NMR}$ $\left(74.5 \mathrm{MHz} \mathrm{CDCl}_{3}\right) \delta 157.7$ (q, $\left.J_{C F}=36.8 \mathrm{~Hz}, 1 \mathrm{C}\right), 151.1,150.2$, 127.7, 117.9, 116.0 (q, $J_{C F}=283.9 \mathrm{~Hz}, \mathrm{CF}_{3}$ ), 114.6, 111.9, 55.9, 41.5, 29.2. ${ }^{19} \mathrm{~F}-\mathrm{NMR}\left(282.2 \mathrm{MHz}, \mathrm{CDCl}_{3}\right)-76.2$ (s, 3F).

4.2.5 N-(4-chloro-5-hydroxy-2-methoxyphenethyl)-2,2,2trifluoroacetamide (6)

Compound 5 (89.5 mg, $0.34 \mathrm{mmol}$ ) was dissolved in ACN (2 $\mathrm{mL}$ ) and NCS (45.5 mg, $0.34 \mathrm{mmol}$ ) was added. The reaction mixture was stirred at $75{ }^{\circ} \mathrm{C}$ for $30 \mathrm{~min}$ and left to cool to room temperature. The solvent was evaporated in vacuum and the crude was purified using preparative LC to gain compound 6 (74.3 mg, 73\% yield) as a white solid. ${ }^{1} \mathrm{H}-\mathrm{NMR}\left(300 \mathrm{MHz}, \mathrm{CDCl}_{3}\right) \delta 6.84$ (s, 1H), 6.82 (s, 1H), 3.79 (s, 3H), 3.59-3.49 (m, 2H), 2.86-2.81 (m, 2H).

4.2.6 5-(2-aminoethyl)-2-chloro-4-methoxyphenol (7) and 2chloro-4-methoxy-5-(2-((2-methoxybenzyl)amino)ethyl)phenol (8)

$\mathrm{NaOH}$ (aq.) ( $86 \mu \mathrm{l}, 0.998 \mathrm{mmol}, 5 \mathrm{M})$ was added to a solution of compound 6 (74.3 mg, $0.25 \mathrm{mmol})$ in EtOH $(1.5 \mathrm{~mL})$ and the reaction mixture was stirred at room temperature for $2 \mathrm{~h}$. The $\mathrm{pH}$ was adjusted to around 10 using $\mathrm{HCl}$ (aq.) and the solution was extracted using DCM (5 x $10 \mathrm{~mL}$ ). The solvent was evaporated in vacuum and the resulting product (compound 7) was re-dissolved in EtOH (2 mL). 2-methoxy benzaldehyde (33 $\mu \mathrm{L}, 0.275 \mathrm{mmol}$ ) and sodium cyanoborohydride (31.4 mg, $0.499 \mathrm{mmol}$ ) was added to the solution that was left to stir at room temperature overnight. Finally sodium borohydride $(9.44 \mathrm{mg}, 0.25 \mathrm{mmol}$ ) was added to the solution and left to stir for about $1 \mathrm{~h}$. The solvent was evaporated in vacuum and the crude purified using preparative LC to gain product 8 (20.5 mg, 26\% yield) as colorless syrupy. ${ }^{1} \mathrm{H}$ NMR (300 MHz, $\left.\mathrm{CDCl}_{3}\right) \delta 7.21(\mathrm{td}, J=8.0,1.7 \mathrm{~Hz}, 1 \mathrm{H}), 7.14$ (dd, $J=8.0,1.7 \mathrm{~Hz}, 1 \mathrm{H}), 6.85$ (td, $J=8.0,1.0 \mathrm{~Hz}, 1 \mathrm{H}), 6.77$ (dd, $J=$ 8.0, $1.0 \mathrm{~Hz}, 1 \mathrm{H}), 6.73$ (s, 1H), 6.68 (s, $1 \mathrm{H}), 3.80$ (s, $2 \mathrm{H}), 3.65$ (s, $3 \mathrm{H}), 3.58$ (s, 3H), 2.85 (t, $J=5.9 \mathrm{~Hz}, 2 \mathrm{H}), 2.75$ (t, $J=5.9 \mathrm{~Hz}, 2 \mathrm{H})$. ${ }^{13} \mathrm{C}-\mathrm{NMR}\left(75 \mathrm{MHz}, \mathrm{CDCl}_{3}\right) \delta 157.7,150.9,146.8,130.8,129.1$, 127.1, 125.6, 120.5, 118.5, 118.1, 112.3, 110.2, 56.0, 55.2, 49.1, 46.6, 30.2. ESI-HRMS positive mode $(\mathrm{m} / \mathrm{z})$ : calcd. for $\mathrm{C}_{17} \mathrm{H}_{21}{ }^{35} \mathrm{ClNO}_{3}\left([\mathrm{M}+\mathrm{H}]^{+}\right)$: 322.1210. Found: 322.1217; calcd. for $\mathrm{C}_{17} \mathrm{H}_{21}{ }^{37} \mathrm{ClNO}_{3}\left([\mathrm{M}+\mathrm{H}]^{+}\right)$: 324.1180. Found: 324.1182.

\subsection{7 (E)-4-methoxy-2-(2-nitrovinyl)phenol (10)}

A mixture of 2-hydroxy-5-methoxybenzaldehyde 9 (76.1 mg, $0.5 \mathrm{mmol})$, nitromethane $(0.82 \mathrm{~mL}, 15.3 \mathrm{mmol})$ and ammonium acetate (38.5 mg, $0.5 \mathrm{mmol}$ ) in a microwave vial was irradiated under $\mathrm{MW}$ at $120{ }^{\circ} \mathrm{C}$ for $70 \mathrm{~min}$. The reaction mixture was cooled to room temperature, water was added and extracted using EtOAc (3 x $10 \mathrm{~mL}$ ). The solvent was evaporated in vacuum and the crude was purified using flash-column chromatography (nheptane/EtOAc 1:1) to gain compound $\mathbf{1 0}^{19}$ (67.4 $\mathrm{mg}, 68 \%$ yield). ${ }^{1} \mathrm{H}-\mathrm{NMR}\left(300 \mathrm{MHz}, \mathrm{CDCl}_{3}\right) \delta 8.11(\mathrm{~d}, J=13.6 \mathrm{~Hz}, 1 \mathrm{H}), 7.90$ (d, $J=13.6 \mathrm{~Hz}, 1 \mathrm{H}), 6.96-6.88(\mathrm{~m}, 2 \mathrm{H}), 6.82-6.74(\mathrm{~m}, 1 \mathrm{H}), 5.33$ (broad s, $1 \mathrm{H}), 3.80$ (s, 3H). ${ }^{13} \mathrm{C}-\mathrm{NMR}(75 \mathrm{MHz}, \mathrm{MeOD}) \delta 154.4$, 153.9, 139.0, 136.8, 121.5, 118.8, 118.1, 115.9, 56.4.

\subsubsection{2-(2-aminoethyl)-4-methoxyphenol (11)}

Compound 10 (247 mg, $1.27 \mathrm{mmol}$ ) was dissolved in THF (8 $\mathrm{mL}$ ) and cooled to $0^{\circ} \mathrm{C}$. $\mathrm{LiAlH}_{4}(5.1 \mathrm{~mL}, 1 \mathrm{M}$ in THF solution) was added dropwise and the reaction mixture was left to stir under nitrogen gas flow at $65{ }^{\circ} \mathrm{C}$ for $4 \mathrm{~h}$. Cold water was added to the 
reaction along with $15 \% \mathrm{NaOH}$ (aq.) in excess and some additional THF. The solution was vacuum filtered and the filtrate was evaporated in vacuum and pre-absorbed on to silica gel before purification using flash-column chromatography (DCM/MeOH/Et ${ }_{3} \mathrm{~N}$ 90:10:1) to gain compound $\mathbf{1 1}^{20}$ (150 mg, 71\% yield). ${ }^{1} \mathrm{H}-\mathrm{NMR}\left(300 \mathrm{MHz}, \mathrm{CDCl}_{3}\right) \delta 6.84(\mathrm{~d}, J=8.7 \mathrm{~Hz}$, 1H), 6.67 (dd, $J=8.7,3.0 \mathrm{~Hz}, 1 \mathrm{H}$ ), 6.58 (d, $J=3 \mathrm{~Hz}, 1 \mathrm{H}$ ), 3.73 (s, $3 \mathrm{H}$ ), 3.10-3.03 (m, 2H), 2.80-2.72 (m, 2H). ${ }^{13} \mathrm{C}-\mathrm{NMR}$ (75 MHz, $\left.\mathrm{CDCl}_{3}\right) \delta 152.8,150.6,128.8,118.1,116.7,113.0,55.9,42.6$, 36.2.

\subsubsection{4-methoxy-2-(2-(2,2,2-trifluoroacetamido)ethyl)phenyl acetate (12)}

Compound 11 (75.2 mg, $0.45 \mathrm{mmol}$ ) was dissolved in THF (1 $\mathrm{mL})$ and trifluoroacetic anhydride (125 $\mu \mathrm{L}, 0.899 \mathrm{mmol})$ and $\mathrm{Et}_{3} \mathrm{~N}$ (125 $\mu \mathrm{L}, 0.899 \mathrm{mmol})$ was added to the solution. The reaction mixture was stirred at room temperature overnight. The solvent was evaporated in vacuum, water was added to the crude and then extracted using DCM (3 x $15 \mathrm{~mL}$ ). The solvent was once again evaporated in vacuum and the crude product was re-dissolved in $\mathrm{CHCl}_{3}(2 \mathrm{~mL})$. Acetyl chloride $(47 \mu \mathrm{L}, 0.54 \mathrm{mmol})$ and $\mathrm{Et}_{3} \mathrm{~N}(81$ $\mu \mathrm{L}, 0.58 \mathrm{mmol}$ ) were added to the solution and stirred at room temperature overnight. Saturated $\mathrm{NaHCO}_{3}$ (aq.) was added to the solution and the organic phase was removed and evaporated in vacuum. The crude was purified using flash-column chromatography (n-heptane/EtOAc 2:1) to gain compound 12 (70.6 mg, 51\% yield). ${ }^{1} \mathrm{H}-\mathrm{NMR}\left(300 \mathrm{MHz}, \mathrm{CDCl}_{3}\right) \delta 6.96(\mathrm{~d}, J=$ $8.8 \mathrm{~Hz}, 1 \mathrm{H}$ ), 6.80 (dd, $J=8.8,3.0 \mathrm{~Hz}, 1 \mathrm{H}), 6.74$ (d, J = 3.0 Hz, 1H), 6.66 (broad s, 1H), 3.78 (s, 3H), 3.62-3.50 (m, 2H), 2.77 (t, $J$ $=6.9 \mathrm{~Hz}, 2 \mathrm{H}), 2.32(\mathrm{~s}, 3 \mathrm{H}) .{ }^{13} \mathrm{C}-\mathrm{NMR}\left(75 \mathrm{MHz}, \mathrm{CDCl}_{3}\right) \delta 170.5$, 157.8, 142.8, 130.9, 123.6, 115.9 (q, $J_{C F}=284.1 \mathrm{~Hz}, \mathrm{CF}_{3}$ ), 115.5, 113.6, 55.7, 40.3, 29.4, 20.9

\subsubsection{5-chloro-4-methoxy-2-(2-(2,2,2-trifluoroacetamido)ethyl)} phenyl acetate $(\mathbf{1 3 a})$

Compound 12 (53.3 mg, $0.175 \mathrm{mmol}$ ) was dissolved in ACN (1 $\mathrm{mL}$ ) and NCS $(25.7 \mathrm{mg}, 0.192 \mathrm{mmol})$ was added at $0{ }^{\circ} \mathrm{C}$. The reaction mixture was then left to reach room temperature and stirred overnight. The solvent was evaporated in vacuum and the crude was purified using flash-column chromatography (nheptane/EtOAc 2:1) to gain compound 13a (38.4 mg, 65\% yield). ${ }^{1} \mathrm{H}-\mathrm{NMR}\left(300 \mathrm{MHz}, \mathrm{CDCl}_{3}\right) \delta 7.10(\mathrm{~s}, 1 \mathrm{H}), 6.74(\mathrm{~s}, 1 \mathrm{H}), 6.60$ (broad s, 1H), 3.87 (s, 3H), 3.61-3.50 (m, 2H), 2.78 (t, $J=6.9 \mathrm{~Hz}$, 2H), 2.32 (s, 3H). ${ }^{13} \mathrm{C}-\mathrm{NMR}\left(75 \mathrm{MHz}, \mathrm{CDCl}_{3}\right) \delta 170.0,153.4$, 142.3, 129.2, 124.5, 121.6, 115.7 (q, $J_{C F}=284.7 \mathrm{~Hz}, \mathrm{CF}_{3}$ ), 113.0, 56.5, 39.9, 29.1, 20.7 .

\subsubsection{5-iodo-4-methoxy-2-(2-(2,2,2-trifluoroacetamido)ethyl) phenyl acetate $(\mathbf{1 3 b})$}

$\mathrm{N}$-iodosuccinimide (24.2 $\mathrm{mg}, 0.108 \mathrm{mmol}$ ) was added to a solution of compound 12 (26.4 mg, $0.086 \mathrm{mmol})$ in AcOH (1 mL) and. After $4 \mathrm{~h}$, the conversion was about $50 \%$ according to LCMS. Additional $N$-iodosuccinimide $(9.70 \mathrm{mg}, 0.043 \mathrm{mmol})$ was added along with $\mathrm{H}_{2} \mathrm{SO}_{4}(2.4 \mu \mathrm{L}, 18 \mathrm{M}, 0.043 \mathrm{mmol})$ and the reaction mixture was stirred overnight. An excess of $\mathrm{Na}_{2} \mathrm{~S}_{2} \mathrm{O}_{3}$ (aq.) and $\mathrm{Et}_{2} \mathrm{O}$ was added to the reaction mixture and the water phase was removed. The solvent was evaporated in vacuum and the crude purified using flash-column chromatography (nheptane/EtOAc 2:1) to gain compound $\mathbf{1 3 b}$ (24 mg, 65\% yield). ${ }^{1} \mathrm{H}-\mathrm{NMR}\left(300 \mathrm{MHz}, \mathrm{CDCl}_{3}\right) \delta 7.46$ (s, 1H), 6.63 (s, 1H), 6.56 (broad s, 1H), 3.85 (s, 3H), 3.62-3.52 (m, 2H), 2.77 (t, $J=6.8,2 \mathrm{H}$ ), $2.32(\mathrm{~s}, 3 \mathrm{H})$

4.2.10 2-(2-aminoethyl)-5-chloro-4-methoxyphenol (14a) and 5chloro-4-methoxy-2-(2-((2-methoxybenzyl)amino)ethyl)phenol (15a)

$\mathrm{NaOH}$ (aq.) (40 $\mu \mathrm{L}, 0.223 \mathrm{mmol}, 5 \mathrm{M})$ was added to a solution of compound 13a (38.4 mg, $0.113 \mathrm{mmol}$ ) in EtOH (1 mL) and the reaction mixture was stirred at room temperature overnight. The pH was adjusted to around 8-9 using $1 \mathrm{~N} \mathrm{HCl}$ (aq.) and the solution was extracted using DCM ( 3 x $10 \mathrm{~mL})$. The solvent was evaporated and part of the resulting compound 14a (11.7 mg, $0.0582 \mathrm{mmol})$ was re-dissolved in DCE (1 mL). 2-methoxy benzaldehyde ( $7.7 \mu \mathrm{L}, 0.0640 \mathrm{mmol}$ ), sodium cyanoborohydride (7.3 mg, $0.116 \mathrm{mmol}$ ) and one drop of $\mathrm{AcOH}$ were added to the solution, which was stirred at room temperature overnight. The solvent was evaporated in vacuum and the crude purified using flash-column chromatography (DCM/MeOH/ $\mathrm{Et}_{3} \mathrm{~N}$ 96:4:1) and preparative LC to gain product 15a (6.8 $\mathrm{mg}, 36 \%$ yield) as colorless syrupy. ${ }^{1} \mathrm{H}-\mathrm{NMR}\left(300 \mathrm{MHz}, \mathrm{CDCl}_{3}\right) \delta 7.29$ (td, $J=7.7$, $1.1 \mathrm{~Hz}, 1 \mathrm{H}$ ), 7.21 (dd, $J=7.7,1.7 \mathrm{~Hz}, 1 \mathrm{H}), 6.98$ (s, 1H), 6.96-6.85 (m, 2H), 6.57 (s, 1H), 3.90 (s, 2H), 3.86 (s, 3H), 3.81 (s, 3H), 2.972.87 (m, 2H), 2.85-2.72 (m, 2H). ${ }^{13} \mathrm{C}-\mathrm{NMR}\left(75 \mathrm{MHz}, \mathrm{CDCl}_{3}\right) \delta$ 157.7, 151.5, 147.9, 130.8, 129.6, 126.4, 121.5, 120.8, 120.4, 119.4, 115.6, 110.6, 57.2, 55.5, 49.0, 48.9, 33.3. ESI-HRMS positive mode $(\mathrm{m} / \mathrm{z})$ : calcd. for $\mathrm{C}_{17} \mathrm{H}_{21}{ }^{35} \mathrm{ClNO}_{3}\left([\mathrm{M}+\mathrm{H}]^{+}\right)$: 322.1210. Found: 322.1211; calcd. for $\mathrm{C}_{17} \mathrm{H}_{21}{ }^{37} \mathrm{ClNO}_{3}\left([\mathrm{M}+\mathrm{H}]^{+}\right)$: 324.1180. Found: 324.1180 .

\subsubsection{2-(2-aminoethyl)-5-iodo-4-methoxyphenol (14b) and 5- iodo-4-methoxy-2-(2-((2-methoxybenzyl)amino)ethyl)phenol (15b)}

$\mathrm{NaOH}$ (aq.) ( $20 \mu \mathrm{L}, 0.111 \mathrm{mmol}, 5 \mathrm{M}$ ) was added to a solution of compound 13b (24 mg, $0.0557 \mathrm{mmol})$ in EtOH $(0.5 \mathrm{~mL})$ and water $(0.5 \mathrm{~mL})$ and the reaction mixture was stirred at room temperature overnight. The $\mathrm{pH}$ was adjusted to around 8-9 using $1 \mathrm{~N} \mathrm{HCl} \mathrm{(aq.)} \mathrm{and} \mathrm{the} \mathrm{solution} \mathrm{was} \mathrm{extracted} \mathrm{using} \mathrm{DCM} \mathrm{(3} \mathrm{x} 10$ $\mathrm{mL}$ ). The solvent was evaporated in vacuum and the resulting compound 14b (15.8 mg, $0.0539 \mathrm{mmol}$ ) was re-dissolved in DCE (1 mL). 2-methoxy benzaldehyde (7.2 $\mu \mathrm{L}, 0.0593 \mathrm{mmol})$, sodium cyanoborohydride (6.8 mg, $0.108 \mathrm{mmol}$ ) and one drop of AcOH were added to the solution that was left to stir at room temperature for about $2 \mathrm{~h}$. The solvent was evaporated in vacuum and the crude purified using flash-column chromatography (DCM/MeOH/Et ${ }_{3} \mathrm{~N}$ 98:2:1) and preparative LC to gain product 15b $(5.8 \mathrm{mg}, 25 \%$ yield) as pale yellow syrupy. ${ }^{1} \mathrm{H}-\mathrm{NMR}\left(300 \mathrm{MHz}, \mathrm{CDCl}_{3}\right) \delta 7.32-$ 7.28 (m, 2H), 7.18 (dd, $J=7.4,1.7 \mathrm{~Hz}, 1 \mathrm{H}), 6.96-6.86(\mathrm{~m}, 2 \mathrm{H})$, 6.48 (s, 1H), 3.85 (s, 5H), 3.78 (s, 3H), 2.91-2.82 (m, 2H), 2.79$2.71(\mathrm{~m}, 2 \mathrm{H}) .{ }^{13} \mathrm{C}-\mathrm{NMR}\left(75 \mathrm{MHz}, \mathrm{CDCl}_{3}\right) \delta 157.9,152.4,151.3$, 130.7, 129.4, 128.7, 128.2, 125.8, 120.8, 114.1, 110.5, 84.1, 57.4, 55.4, 49.1, 49.0, 34.2. ESI-HRMS positive mode (m/z): calcd. for $\mathrm{C}_{17} \mathrm{H}_{21} \mathrm{INO}_{3}\left([\mathrm{M}+\mathrm{H}]^{+}\right)$: 414.0566. Found: 414.0569.

\subsubsection{Tert-butyl 2,5-dimethoxyphenethylcarbamate (17)}

A mixture of 3-(2,3-dimethoxyphenyl) propionic acid 16 (200 $\mathrm{mg}, 0.950 \mathrm{mmol}$ ), sodium azide (216 mg, $3.33 \mathrm{mmol}$ ), tetrabutylammonium bromide ( $45.6 \mathrm{mg}, 0.143 \mathrm{mmol}$ ), zinc triflate (11.4 mg, $31.4 \mu \mathrm{mol}$ ) and di-tert-butyldicarbonate (228 mg, 1.05 mmol) in dry THF $(9.5 \mathrm{~mL})$ was stirred at $40{ }^{\circ} \mathrm{C}$ under nitrogen overnight. When the reaction was completed according to LC-MS, 
a $10 \% \mathrm{NaNO}_{2}$ aq. solution (6 mL) was added along with EtOAc $(6 \mathrm{~mL})$ and the reaction mixture was left stir at room temperature for $20 \mathrm{~min}$. The water phase was extracted using additional EtOAc $(3 \times 6 \mathrm{~mL})$ and the organic phases were combined and washed with saturated aq. $\mathrm{NH}_{4} \mathrm{Cl}(6 \mathrm{~mL})$, saturated $\mathrm{Na}_{2} \mathrm{SO}_{4}(6 \mathrm{~mL})$ and saturated $\mathrm{NaHCO}_{3}(6 \mathrm{~mL})$. The solvent was evaporated in vacuum and the crude product purified using flash-column chromatography (n-heptane/EtOAc 3:1). The fractions containing the product were concentrated in vacuum to afford compound $\mathbf{1 7}^{21}$ (192 mg, 72\% yield) as a white solid. ${ }^{1} \mathrm{H}-\mathrm{NMR}\left(300 \mathrm{MHz}, \mathrm{CDCl}_{3}\right.$ ) $\delta$ 6.79-6.68 (m, 3H), 4.68 (broad s, 1H), 3.76 (s, 3H), 3.74 (s, 3H), 3.39-3.26 (m, 2H), 2.77 (t, $J=6.8 \mathrm{~Hz}, 2 \mathrm{H}), 1.42$ (s, 9H). ${ }^{13} \mathrm{C}-\mathrm{NMR}$ $\left(75 \mathrm{MHz}, \mathrm{CDCl}_{3}\right) \delta 156.0,153.6,151.9,128.7,116.9,111.9$, 111.4, 79.0, 55.9, 55.7, 40.7, 31.0, 28.5.

\subsubsection{2-(2-((tert-butoxycarbonyl)amino)ethyl)-5-chloro-4-} methoxyphenyl acetate (18a)

The mixture of 17 (50.2 mg, $0.178 \mathrm{mmol}$ ) and NCS (25.0, 0.187 $\mathrm{mmol})$ in acetonitrile $(1 \mathrm{~mL})$ was irradiated under microwave at $75{ }^{\circ} \mathrm{C}$ for $30 \mathrm{~min}$. The mixture was purified directly using preparative LC to give compound 18a (47 $\mathrm{mg}, 84 \%$ yield) as a white solid. ${ }^{1} \mathrm{H}-\mathrm{NMR}\left(300 \mathrm{MHz}, \mathrm{CDCl}_{3}\right) \delta 6.86(\mathrm{~s}, 1 \mathrm{H}), 6.74(\mathrm{~s}$, $1 \mathrm{H}), 3.83$ (s, 3H), 3.76 (s, 3H), 3.38-3.25 (m, 2H), 2.76 (d, $J=6.6$ $\mathrm{Hz}, 2 \mathrm{H}), 1.42$ (s, 9H). ${ }^{13} \mathrm{C}-\mathrm{NMR}\left(\mathrm{CDCl}_{3}, 75 \mathrm{~Hz}\right) \delta 156.1,151.8$, 149.1, 127.0, 120.5, 115.4, 113.1, 79.2, 57.0, 56.1, 40.6, 30.8, 28.5 .

\subsubsection{2-(2-((tert-butoxycarbonyl)amino)ethyl)-5-iodo-4-} methoxyphenyl acetate (18b)

A mixture of compound 17 (434 mg, $1.54 \mathrm{mmol}$ ) and $\mathrm{N}$ iodosuccinimide (434 mg, $1.93 \mathrm{mmol})$ in $\mathrm{AcOH}(12 \mathrm{~mL})$ was stirred at room temperature for $4 \mathrm{~h}$. When the reaction was completed according to LC-MS an excess amount of saturated $\mathrm{Na}_{2} \mathrm{SO}_{3}$ (aq.) was added to the reaction mixture and the water phase was then extracted using DCM ( 3 x $10 \mathrm{~mL})$. The solvent was evaporated in vacuum and the crude product was purified using flash-column chromatography twice i) n-heptane/EtOAc 2:1; ii) $\mathrm{DCM} / \mathrm{MeOH}$ (98.4:0.6) to give compound $\mathbf{1 8 b}^{22}$ (411 mg, 65\% yield) as a white solid. ${ }^{1} \mathrm{H}-\mathrm{NMR}\left(300 \mathrm{MHz}, \mathrm{CDCl}_{3}\right) \delta 7.21(\mathrm{~s}, 1 \mathrm{H})$, 6.64 (s, 1H), 4.61 (broad s, 1H), 3.81 (s, 3H), 3.77 (s, 3H), 3.363.25 (m, 2H), 2.76 (t, $J=6.9 \mathrm{~Hz}, 2 \mathrm{H}), 1.41$ (s, 9H). ${ }^{13} \mathrm{C}-\mathrm{NMR}(75$ $\left.\mathrm{MHz}, \mathrm{CDCl}_{3}\right) \delta 156.0,152.6,152.5,128.9,121.7,114.0,82.9$, 79.3, 57.2, 56.2, 40.6, 31.2, 28.5.

\subsubsection{2-(((4-iodo-2,5-dimethoxyphenethyl)amino)methyl)phenol} (19)

Deprotection of 18b:

TFA (1.35 mL) was added dropwise to a solution of compound 18b (367 mg, $0.902 \mathrm{mmol}$ ) in DCM (1.5 mL). The reaction mixture was left to stir at room temperature for about $1 \mathrm{~h}$. When the reaction was completed according to LC-MS the solvent was evaporated in vacuum and saturated $\mathrm{NaHCO}_{3}$ (aq.) was added to adjust the $\mathrm{pH}$ to around 8-9. The product was then extracted using DCM (3 x $10 \mathrm{~mL})$ and the solvent was removed in vacuum to give the amine (275 mg, 99\% yield). The amine was used further for the synthesis of compound $\mathbf{1 9}$ and $\mathbf{2 1 b}$.

Reductive amination:

$\mathrm{Et}_{3} \mathrm{~N}(28.4 \mu \mathrm{L}, 0.204 \mathrm{mmol})$ was added to a solution of resulting amine (62.6 mg, $0.204 \mathrm{mmol}$ ) in EtOH (2 mL). The reaction was monitored by TLC and after two hours a full conversion of the starting material had occurred and an imine had formed. $\mathrm{NaBH}_{4}$ (15.4 mg, $0.407 \mathrm{mmol}$ ) was added and the mixture was stirred for 30 min. The solvent was evaporated and the $\mathrm{pH}$ of the crude mixture was adjusted to around 8-9 using $\mathrm{K}_{2} \mathrm{CO}_{3}$ (aq.). The mixture was extracted using DCM ( $3 \times 10 \mathrm{~mL})$ and the crude was then purified using flash-column chromatography twice i) $\mathrm{DCM} / \mathrm{MeOH} / \mathrm{Et}_{3} \mathrm{~N}$ 92:8:1; ii) n-heptane/EtOAc/Et ${ }_{3} \mathrm{~N}$ 99:1:1) and preparative LC to gain the final product 4 (16.3 mg, $19 \%$ yield) as pale yellow syrupy. The low yield was due to the problem of purification. ${ }^{1} \mathrm{H}-\mathrm{NMR}\left(300 \mathrm{MHz}, \mathrm{CDCl}_{3}\right) \delta 7.22(\mathrm{~s}, 1 \mathrm{H}), 7.16(\mathrm{td}$, $J=7.8,1.5 \mathrm{~Hz}, 1 \mathrm{H}$ ), 6.97 (dd, $J=7.8 \mathrm{~Hz}, 1.5 \mathrm{~Hz}, 1 \mathrm{H}$ ), 6.82 (br d, $J=7.8 \mathrm{~Hz}, 1 \mathrm{H}$ ), 6.76 (br t, $J=7.8 \mathrm{~Hz}, 1 \mathrm{H}), 6.65$ (s, 1H), 3.98 (s, 2H), 3.82 (s, 3H), 3.76 (s, 3H), 2.91 (t, $J=6.1 \mathrm{~Hz}, 2 \mathrm{H}), 2.82$ (t, $J$ $=6.1 \mathrm{~Hz}, 2 \mathrm{H}) .{ }^{13} \mathrm{C}-\mathrm{NMR}\left(75 \mathrm{MHz}, \mathrm{CDCl}_{3}\right) \delta 158.4,152.7,152.5$, 128.9, 128.8, 128.4, 122.6, 121.8, 119.1, 116.5, 113.8, 83.1, 57.3, 56.2, 52.6, 48.3, 30.9. ESI-HRMS positive mode (m/z): calcd. for $\mathrm{C}_{17} \mathrm{H}_{21} \mathrm{INO}_{3}\left([\mathrm{M}+\mathrm{H}]^{+}\right)$: 414.0566. Found: 414.0576.

\subsubsection{4-(((4-iodo-2,5-dimethoxyphenethyl)amino)methyl)-3- methoxyphenol (21b)}

To the resulting amine (33.4 mg, $0.109 \mathrm{mmol}$ ) in EtOH (1.5 $\mathrm{mL}$ ), which was achieved from $\mathbf{1 8 b}$ after deprotection in the synthesis of compound 19, 4-hydroxy-2-methoxybenzaldehyde (18.2 mg, $0.12 \mathrm{mmol}$ ) was added. The reaction was monitored by TLC and after two hours a full conversion of the starting material had occurred and an imine had formed. $\mathrm{NaBH}_{4}$ (14.4 mg, 0.381 mmol) was then added and the mixture was stirred overnight. The solvent was evaporated and the $\mathrm{pH}$ of the crude mixture was adjusted to around 8-9 using $\mathrm{K}_{2} \mathrm{CO}_{3}$ (aq.). The mixture was extracted using DCM ( $3 \times 10 \mathrm{~mL})$ and the crude was then purified first using flash-column chromatography (DCM/MeOH/Et ${ }_{3} \mathrm{~N}$ 95:5:1) and recrystallization by dissolving the crude in $\mathrm{MeOH}(0.5$ $\mathrm{mL}$ ), adding $\mathrm{HCl}$ ( $28 \mu \mathrm{L}, 2 \mathrm{M}$ in ether solution) and then dilute with $\mathrm{Et}_{2} \mathrm{O}$ until crystallization and then recrystallize the product using $\mathrm{i}-\mathrm{PrOH}$ and $\mathrm{Et}_{2} \mathrm{O}$. The product was dissolved in water $(3 \mathrm{~mL})$, adjusted $\mathrm{pH}$ to about 9 using $\mathrm{K}_{2} \mathrm{CO}_{3}$ (aq.), extracted with DCM (3 x $5 \mathrm{~mL}$ ), concentrated to give the product $21 \mathrm{~b}$ (23.6 mg, 49\% yield) as pale yellow syrupy. ${ }^{1} \mathrm{H}-\mathrm{NMR}\left(300 \mathrm{MHz}, \mathrm{CDCl}_{3}\right) \delta 7.21$ (s, 1H), 6.84 (d, $J=8.0 \mathrm{~Hz}, 1 \mathrm{H}), 6.69$ (s, 1H), 6.20 (d, $J=2.0 \mathrm{~Hz}$, $1 \mathrm{H}$ ), 6.05 (dd, $J=8.0,2.0 \mathrm{~Hz}, 1 \mathrm{H}$ ), 3.77 (s, 3H), 3.74 (s, 3H), 3.69 (s, 2H), 3.59 (s, 3H), 2.96-2.84 (m, 4H). ${ }^{13} \mathrm{C}-\mathrm{NMR}(75 \mathrm{MHz}$, $\left.\mathrm{CDCl}_{3}\right) \delta 158.6,158.1,152.7,152.6,131.2,129.1,121.9,114.1$, 107.6, 99.6, 82.9, 57.2, 56.3, 55.2, 49.2, 48.4, 30.6. ESI-HRMS positive mode $(\mathrm{m} / \mathrm{z})$ : calcd. for $\mathrm{C}_{18} \mathrm{H}_{23} \mathrm{INO}_{4}\left([\mathrm{M}+\mathrm{H}]^{+}\right)$: 444.0672 . Found: 444.0668.

\subsection{General procedure for synthesis of 20, 21a, 22 and 23}

\subsubsection{Chlorination}

The mixture of 17 (102 mg, $0.363 \mathrm{mmol}$ ) and NCS (50.9 mg, 0.381 $\mathrm{mmol})$ in acetonitrile $(2 \mathrm{~mL})$ was irradiated under microwave at $75^{\circ} \mathrm{C}$ for $30 \mathrm{~min}$ or under conventional heating at $75^{\circ} \mathrm{C}$ for $1 \mathrm{~h}$. The reaction was analyzed using LC-MS. The mixture was concentrated followed by adding $3 \mathrm{~mL}$ water. The mixture was extracted with DCM ( 3 x $3 \mathrm{~mL}$ ) and concentrated to give the crude product for next step without further purification.

\subsubsection{Deprotection}

To the crude product $(0.363 \mathrm{mmol})$ in DCM (2 mL), TFA (277.8 $\mathrm{uL}, 3.63 \mathrm{mmol}$ ) was added. The mixture was stirred overnight at 
rt. The mixture was concentrated, co-evaporated with DCM three times to remove excess amount of TFA. The crude product was about $140 \mathrm{mg}$, suggesting the amount of TFA is $0.526 \mathrm{mmol}, 1.5$ equiv. of the free amine because the reaction gave full conversion. The mixture was dissolved in $5 \mathrm{~mL}$ 1,2-dichloroethane (DCE) and divided into two parts for reductive amination.

\subsubsection{Reductive amination}

To the crude product $(0.182 \mathrm{mmol})$ in DCE $(2.5 \mathrm{~mL})$ from last step, TEA (38.1 uL, $0.273 \mathrm{mmol}$ ) was added and the mixture was stirred at rt for about $15 \mathrm{~min}$. Aldehyde (30.4 mg, $0.200 \mathrm{mmol}$ ) was then added to the mixture and stirred at rt. The reaction was monitored using LC-MS. The imine formation was not completed after $3 \mathrm{~h}$ for 20, 22 and 23. Reducing reagent $(0.363 \mathrm{mmol}$, $\mathrm{NaCNBH}_{3}$ for 20b, 22 and 23, or $\mathrm{Na}(\mathrm{OAc})_{3} \mathrm{BH}$ for 20a) and EtOH $(1.5 \mathrm{~mL})$ were then added to the mixture and stirred at $\mathrm{rt}$ for $2 \mathrm{~h}$ (20a) or overnight (20b, 22 and 23). The imine formation was completed after $3 \mathrm{~h}$ for $21 \mathrm{a}, \mathrm{NaBH}_{4}(1.09 \mathrm{mmol})$ and $1.5 \mathrm{~mL}$ EtOH were added and stirred at $\mathrm{rt}$ for $2 \mathrm{~h}$. The reaction mixture was then concentrated at $30{ }^{\circ} \mathrm{C}$, re-dissolved in $\mathrm{MeOH}$ and purified using preparative LC and freeze-drying to give the desired product as white solid. The solid became sticky under air atmosphere. Chemical shifts of NMR can be slightly different for the same compound but containing different amount of solvent residue from the preparative LC. Compound 20a was used as an example to show the difference. Its chemical shifts were different when the solvent was removed using freeze-drying or extraction using DCM followed by concentration at about $25^{\circ} \mathrm{C}$.

\subsubsection{3-(((4-chloro-2,5-dimethoxyphenethyl)amino)methyl)-4-} methoxyphenol (20a)

The synthesis was started from 18a (30 mg, $0.0950 \mathrm{mmol}$ ), following the general procedure from the step of deprotection. The reaction mixture was purified using preparative LC. The fractions containing 20a were dried using freeze-drying to give compound 20a (16.4 mg, 49\% yield) as a white solid. ${ }^{1} \mathrm{H}-\mathrm{NMR}\left(\mathrm{CDCl}_{3}, 300\right.$ MHz) $\delta 6.86$ (s, 1H), 6.79 (s, 1H), 6.71 (dd, $J=8.7,2.8 \mathrm{~Hz}, 1 \mathrm{H}$ ), 6.65 (d, $J=8.7 \mathrm{~Hz}, 1 \mathrm{H}), 6.62$ (d, $J=2.8 \mathrm{~Hz}, 1 \mathrm{H}), 3.82$ (s, 3H), 3.79 (s, 2H), 3.71 (s, 3H), 3.63 (s, 3H), 2.99-2.91 (m, 2H), 2.91$2.83(\mathrm{~m}, 2 \mathrm{H}) .{ }^{13} \mathrm{C}-\mathrm{NMR}\left(\mathrm{CDCl}_{3}, 75 \mathrm{MHz}\right) \delta 151.8,151.0,150.97$, 149.2, 125.8, 123.7, 121.0, 118.3, 116.3, 115.6, 113.3, 111.7, 57.0, 56.2, 55.8, 48.0, 47.2, 29.2. ESI-HRMS positive mode $(\mathrm{m} / \mathrm{z})$ : calcd. for $\mathrm{C}_{18} \mathrm{H}_{23}{ }^{35} \mathrm{ClNO}_{4}\left([\mathrm{M}+\mathrm{H}]^{+}\right)$: 352.1316. Found: 352.1316; calcd. for $\mathrm{C}_{18} \mathrm{H}_{23}{ }^{37} \mathrm{ClNO}_{4}\left([\mathrm{M}+\mathrm{H}]^{+}\right)$: 354.1286. Found: 354.1288.

The synthesis was started from compound 17 (51.0 mg, 0.182 $\mathrm{mmol}$ ), following the general procedure step from chlorination. The reaction mixture was purified using preparative LC. To the fractions containing desired product from preparative LC added water (3 mL) and extracted with DCM (4 mL x 8), combined and concentrated to give compound 20a (48.7 mg, 76\% yield) as pale yellow syrupy. ${ }^{1} \mathrm{H}-\mathrm{NMR}\left(\mathrm{CDCl}_{3}, 300 \mathrm{MHz}\right) \delta 6.86(\mathrm{~s}, 1 \mathrm{H}), 6.77$ (s, 1H), 6.65-6.61 (m, 2H), 6.51-6.47 (m, 1H), 3.79 (s, 3H), 3.73 (s, 3H), 3.66 (s, 2H), 3.63 (s, 3H), 2.94-2.81 (m, 4H). ${ }^{13} \mathrm{C}-\mathrm{NMR}$ $\left(\mathrm{CDCl}_{3}, 75 \mathrm{MHz}\right) \delta 151.9,151.2,150.7,149.0,127.4,127.2$, 120.5, 118.9, 115.7, 115.5, 113.2, 111.5, 57.0, 56.2, 55.7, 49.5, 48.7, 30.3. ESI-MS positive mode $(\mathrm{m} / \mathrm{z})$ : calcd. for $\mathrm{C}_{18} \mathrm{H}_{23}{ }^{35} \mathrm{ClNO}_{4}\left([\mathrm{M}+\mathrm{H}]^{+}\right)$: 352.13. Found: 352.42; calcd. for $\mathrm{C}_{18} \mathrm{H}_{23}{ }^{37} \mathrm{ClNO}_{4}\left([\mathrm{M}+\mathrm{H}]^{+}\right)$: 354.13. Found: 354.17.
4.3.5 3-(((4-iodo-2,5-dimethoxyphenethyl)amino)methyl)-4methoxyphenol (20b)

The synthesis was started from 18b (40 mg, $0.098 \mathrm{mmol}$ ), following the general procedure for the synthesis of $\mathbf{2 0 - 2 3}$ from the step of deprotection, the reaction mixture was purified using preparative LC and the fractions containing 20b were dried using freeze-drying to give compound $\mathbf{2 0 b}$ (21.8 $\mathrm{mg}, 50 \%$ yield) as a white solid. ${ }^{1} \mathrm{H}-\mathrm{NMR}\left(\mathrm{CDCl}_{3}, 300 \mathrm{MHz}\right) \delta 7.19$ (s, 1H), 6.776.61 (m, 4H), 3.84 (s, 2H), 3.78 (s, 3H), 3.69 (s, 3H), 3.60 (s, 3H), $2.99(\mathrm{t}, J=6.2 \mathrm{~Hz}, 2 \mathrm{H}), 2.90$ (t, $J=6.2 \mathrm{~Hz}, 2 \mathrm{H}) .{ }^{13} \mathrm{C}-\mathrm{NMR}\left(\mathrm{CDCl}_{3}\right.$, $75 \mathrm{MHz}) \delta$ 152.7, 152.4, 151.03, 150.97, 127.7, 123.8, 121.9, 118.3, 116.3, 114.1, 111.6, 83.5, 57.2, 56.2, 55.8, 48.3, 47.0, 29.6. ESI-HRMS positive mode $(\mathrm{m} / \mathrm{z})$ : calcd. for $\mathrm{C}_{18} \mathrm{H}_{23} \mathrm{INO}_{4}$ $\left([\mathrm{M}+\mathrm{H}]^{+}\right)$: 444.0672. Found: 444.0660 .

\subsubsection{4-(((4-chloro-2,5-dimethoxyphenethyl)amino)methyl)-3- methoxyphenol (21a)}

The synthesis was started from compound 17 (51.0 mg, 0.182 $\mathrm{mmol}$ ), following the general procedure step from chlorination. The reaction mixture was purified using preparative LC. The LC fractions containing desired product were dried using freezedrying to give compound to give 21a (38.4 mg, $60 \%$ yield) as a white solid. ${ }^{1} \mathrm{H}-\mathrm{NMR}\left(\mathrm{CDCl}_{3}, 300 \mathrm{MHz}\right) \delta$ 6.90-6.84 (m, 3H), 6.15-6.02 (m, 2H), 3.83 (s, 3H), 3.77 (s, 2H), 3.76 (s, 3H), 3.56 (s, 3H), 3.04 (t, $J=6.2 \mathrm{~Hz}, 2 \mathrm{H}), 2.94$ (t, $J=6.2 \mathrm{~Hz}, 2 \mathrm{H}) .{ }^{13} \mathrm{C}-\mathrm{NMR}$ $\left(\mathrm{CDCl}_{3}, 75 \mathrm{MHz}\right) \delta 159.0,158.5,151.8,149.2,131.3,126.1$, 121.0, 115.8, 114.4, 113.3, 107.8, 99.4, 57.0, 56.2, 55.2, 48.7, 47.8, 29.5. ESI-HRMS positive mode $(\mathrm{m} / \mathrm{z})$ : calcd. for $\mathrm{C}_{18} \mathrm{H}_{23}{ }^{35} \mathrm{ClNO}_{4}\left([\mathrm{M}+\mathrm{H}]^{+}\right)$: 352.1316. Found: 352.1315; calcd. for $\mathrm{C}_{18} \mathrm{H}_{23}{ }^{37} \mathrm{ClNO}_{4}\left([\mathrm{M}+\mathrm{H}]^{+}\right)$: 354.1286. Found: 354.1287.

4.3.7 3-(((4-chloro-2,5-dimethoxyphenethyl)amino)methyl)-2methoxyphenol (22)

The synthesis was started from compound $\mathbf{1 7}$ (51.0 mg, 0.182 mmol), following the general procedure step from chlorination. The reaction mixture was purified using preparative LC. The LC fractions containing desired product were dried using freezedrying to give compound 22 (17.3 mg, 27\% yield) as a white solid. ${ }^{1} \mathrm{H}-\mathrm{NMR}\left(\mathrm{CDCl}_{3}, 300 \mathrm{MHz}\right) \delta 6.91$ (dd, $\left.J=8.1,7.5 \mathrm{~Hz}, 1 \mathrm{H}\right), 6.86$ (s, 1H), 6.82 (dd, $J=8.1,1.8 \mathrm{~Hz}, 1 \mathrm{H}), 6.77$ (s, 1H), 6.75 (dd, $J=$ 7.5, $1.8 \mathrm{~Hz}, 1 \mathrm{H}$ ), 3.85 (s, 2H), 3.83 (s, 3H), 3.76 (s, 3H), 3.74 (s, $3 \mathrm{H}), 2.96-2.81$ (m, 4H). ${ }^{13} \mathrm{C}-\mathrm{NMR}\left(\mathrm{CDCl}_{3}, 75 \mathrm{MHz}\right) \delta 151.8$, 149.3, 149.1, 145.8, 131.2, 127.0, 125.0, 121.4, 120.6, 116.2, 115.3, 113.2, 61.3, 57.0, 56.2, 48.6, 48.3, 30.3. ESI-HRMS positive mode $(\mathrm{m} / \mathrm{z})$ : calcd. for $\mathrm{C}_{18} \mathrm{H}_{23}{ }^{35} \mathrm{ClNO}_{4}\left([\mathrm{M}+\mathrm{H}]^{+}\right)$: 352.1316. Found: 352.1329; calcd. for $\mathrm{C}_{18} \mathrm{H}_{23}{ }^{37} \mathrm{ClNO}_{4}\left([\mathrm{M}+\mathrm{H}]^{+}\right)$: 354.1286. Found: 354.1294.

\subsubsection{2-(((4-chloro-2,5-dimethoxyphenethyl)amino)methyl)-3- methoxyphenol (23)}

The synthesis was started from compound 17 (51.0 mg, 0.182 mmol), following the general procedure step from chlorination. The reaction mixture was purified using preparative LC. The LC fractions containing desired product were dried using freezedrying to give compound 23 (35.9 mg, 56\% yield) as a white solid. ${ }^{1} \mathrm{H}-\mathrm{NMR}\left(\mathrm{CDCl}_{3}, 300 \mathrm{MHz}\right) \delta 7.09(\mathrm{t}, J=8.4 \mathrm{~Hz}, 1 \mathrm{H}), 6.87(\mathrm{~s}$, $1 \mathrm{H}$ ), 6.75 (s, 1H), 6.50 (dd, $J=8.4,0.9 \mathrm{~Hz}, 1 \mathrm{H}), 6.36$ (dd, $J=8.4$, $0.9 \mathrm{~Hz}, 1 \mathrm{H}), 4.09$ (s, 2H), 3.83 (s, 3H), 3.75 (s, 3H), 3.74 (s, 3H), 3.01-2.80 (m, 4H). ${ }^{13} \mathrm{C}-\mathrm{NMR}\left(\mathrm{CDCl}_{3}, 75 \mathrm{MHz}\right) \delta$ 159.3, 158.0, 151.7, 149.1, 129.3, 126.0, 120.9, 115.3, 113.3, 109.9, 109.0, 
101.6, 57.0, 56.1, 55.7, 47.8, 43.9, 29.8. ESI-HRMS positive mode $(\mathrm{m} / \mathrm{z})$ : calcd. for $\mathrm{C}_{18} \mathrm{H}_{23}{ }^{35} \mathrm{ClNO}_{4}\left([\mathrm{M}+\mathrm{H}]^{+}\right)$: 352.1316 . Found: 352.1322; calcd. for $\mathrm{C}_{18} \mathrm{H}_{23}{ }^{37} \mathrm{ClNO}_{4}\left([\mathrm{M}+\mathrm{H}]^{+}\right)$: 354.1286 . Found: 354.1288.

\section{Acknowledgements}

Financial support from the National Board of Forensic Medicine in Sweden is gratefully acknowledged.

\section{References:}

1. Burke, P. J.; O'Sullivan, J; Vaughan, B. L. Pediatr Emerg Care, 2005, 21, 770-776.

2. EMCDDA highlights growing threads posed by new and established substances, European Drug Report 2017-Highlights.

3. Wood, D. M.; Sedefov, R.; Cunningham, A.; Dargan, P. I. Clin Toxicol (Phila), 2015, 53, 85 - 92.

4. Casale, J. F.; Hays, P. A. Microgram Journals, 2012, 9, 84-109.

5. Forrester, M. B. J Addict Dis, 2014, 33, 196 - 201.

6. Bersani, F. S.; Corazza, O.; Albano, G.; Valeriani G.; Santacroce, R.; Bolzan Mariotti Posocco, F.; Cinosi, E.; Simonato, P.; Martinotti, G.; Bersani, G.; Schifano F. Biomed Res Int, 2014, art. no. 734749 .

7. Kueppers, V. B.; Cooke, C. T. Forensic Sci Int, 2015, 249, 15-18.

8. Shanks, K. G.; Sozio, T.; Behonick, G. S. J Anal Toxicol, 2015, 39, $602-606$.

9. Boumrah, Y.; Humbert, L.; Phanithavong, M.; Khimeche, K.; Dahmani, A.; Allorge, D. Drug testing and analysis, 2016, 8, 248256.
10. Caspar, A. T.; Helfer, A. G.; Michely, J. A.; Auwarter, V.; Brandt, S. D.; Meyer, M. R.; Maurer, H. H. Anal Bioanal Chem, 2015, 407, 6697-6719.

11. Poklis, J. L.; Dempsey, S. K.; Liu, K.; Ritter, J. K.; Wolf, C.; Zhang, S.; Poklis, A. J Anal Toxicol, 2015, 39, 607-616.

12. Okada, Y. H.; Sugai, M.; Chiba, K. J Org Chem, 2016, 81, 1092210929.

13. Wohlfarth, A.; Roman, M.; Andersson, M.; Kugelberg, F. C.; Diao,X.; Carlier, J.; Eriksson, C.; Wu, X.; Konradsson, P.; Josefsson, M.; Huestise M. A.; Kronstrand, R. Drug Test Anal, 2017, 9, 680-698.

14. Lebel, H.; Leogane, O. Org Lett, 2005, 7, 4107-4110.

15. Caspar, A. T.; Brandt, S. D.; Stoever, A. E.; Meyer M. R.; Maurer, H. H. J Pharm Biomed Anal, 2017, 134, 158-169.

16. Leth-Petersen, S.; Gabel-Jensen, C.; Gillings, N.; Lehel, S.; Hansen, H. D.; Knudsen, G. M.; Kristensen, J. L. Chem Res Toxicol, 2016, 29, 96-100.

17. Nielsen, L. M.; Holm, N. B.; Leth-Petersen, S.; Kristensen, J. L.; Olsenb, L.; Linnet, K. Drug Test Anal, 2017, 9, 671-679.

18. Rangisetty, J. B.; Dukat, M.; Dowd, C. S.; Herrick-Davis, K.; DuPre, A.; Gadepalli, S.; Teitler, M.; Kelley, C. R.; Sharif, N. A.; Glennon, R. A. J Med Chem, 2001, 44, 3283-3291.

19. Lu, D.; Li, Y.; Gong, Y. J Org Chem, 2010, 75, 6900-6907.

20. Glennon, R. A.; Liebowitz, S. M.; Leming-Doot, D.; Rosecrans, J. A. J Med Chem, 1980, 23, 990-994.

21. Mori-Quiroz, L. M.; Clift, M. D. Org Lett, 2016, 18, 3446-3449.

22. Trachsel, D.; Nichols, D. E.; Kidd, S.; Hadorn, M.; Baumberger, F. Chem Biodivers, 2009, 6, 692-704.

\section{Supplementary Material}

Supplementary data associated with this article can be found, in the online version, at 


\section{Graphical Abstract}

\section{Synthesis and Identification of Metabolite Biomarkers}

of 25C-NBOMe and 25I-NBOMe

Xiongyu Wu, Caroline Eriksson, Ariane Wohlfarth, Jakob Wallgren, Robert Kronstrand, Martin Josefsson, Johan Dahlén, Peter Konradsson

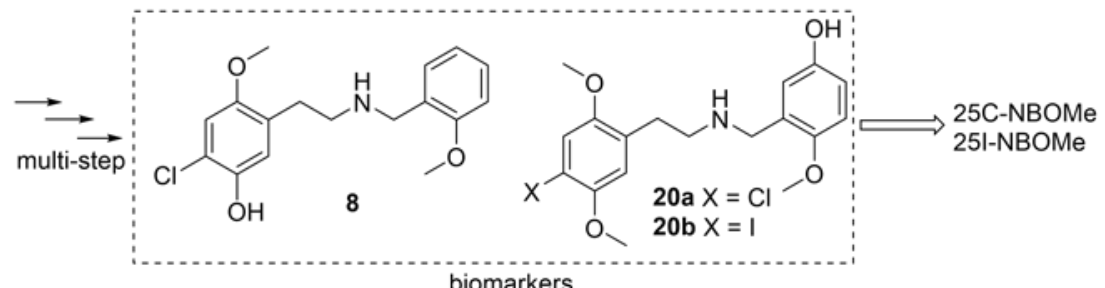




\title{
Supporting information
}

\section{Synthesis and Identification of Metabolite Biomarkers of 25C- NBOMe and 25I-NBOMe}

\author{
Xiongyu $\mathrm{Wu}^{\mathrm{a}}{ }^{*}$, Caroline Eriksson ${ }^{\mathrm{a}}$, Ariane Wohlfarth ${ }^{\mathrm{b}, \mathrm{c}}$, Jakob Wallgren ${ }^{\mathrm{a}}$, Robert \\ Kronstrand $^{\mathrm{b}, \mathrm{c}}$, Martin Josefsson ${ }^{\mathrm{b}, \mathrm{c}}$, Johan Dahlén ${ }^{\mathrm{a}}$, Peter Konradsson ${ }^{\mathrm{a}}$ \\ ${ }^{a}$ Department of Physics, Chemistry and Biology, Linköping University, Sweden \\ ${ }^{b}$ Department of Forensic Genetics and Forensic Toxicology, National Board of Forensic \\ Medicine, Sweden \\ ${ }^{c}$ Division of Drug Research, Department of Medical and Health Sciences, Faculty of Health \\ Sciences, Linköping University, Sweden
}

Copies of NMR spectra of the prepared compounds.

\footnotetext{
*Corresponding author - Tel: +4613284666; E-mail: xiongyu.wu@liu.se
} 
5-hydroxy-2-methoxybenzaldehyde (2) Solvent: $\mathrm{CDCl}_{3}$
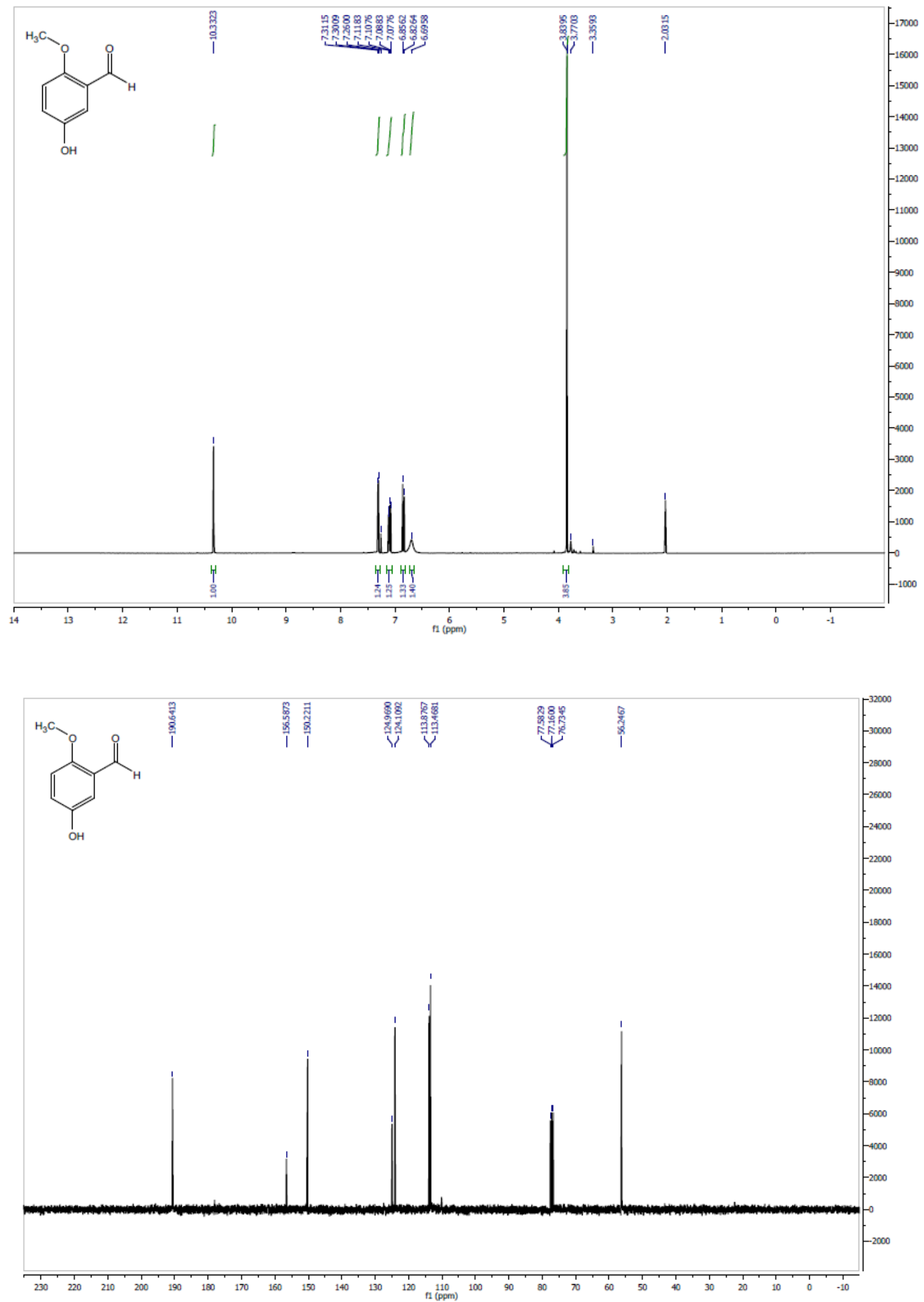
(E)-4-methoxy-3-(2-nitrovinyl)phenol (3) Solvent: MeOD
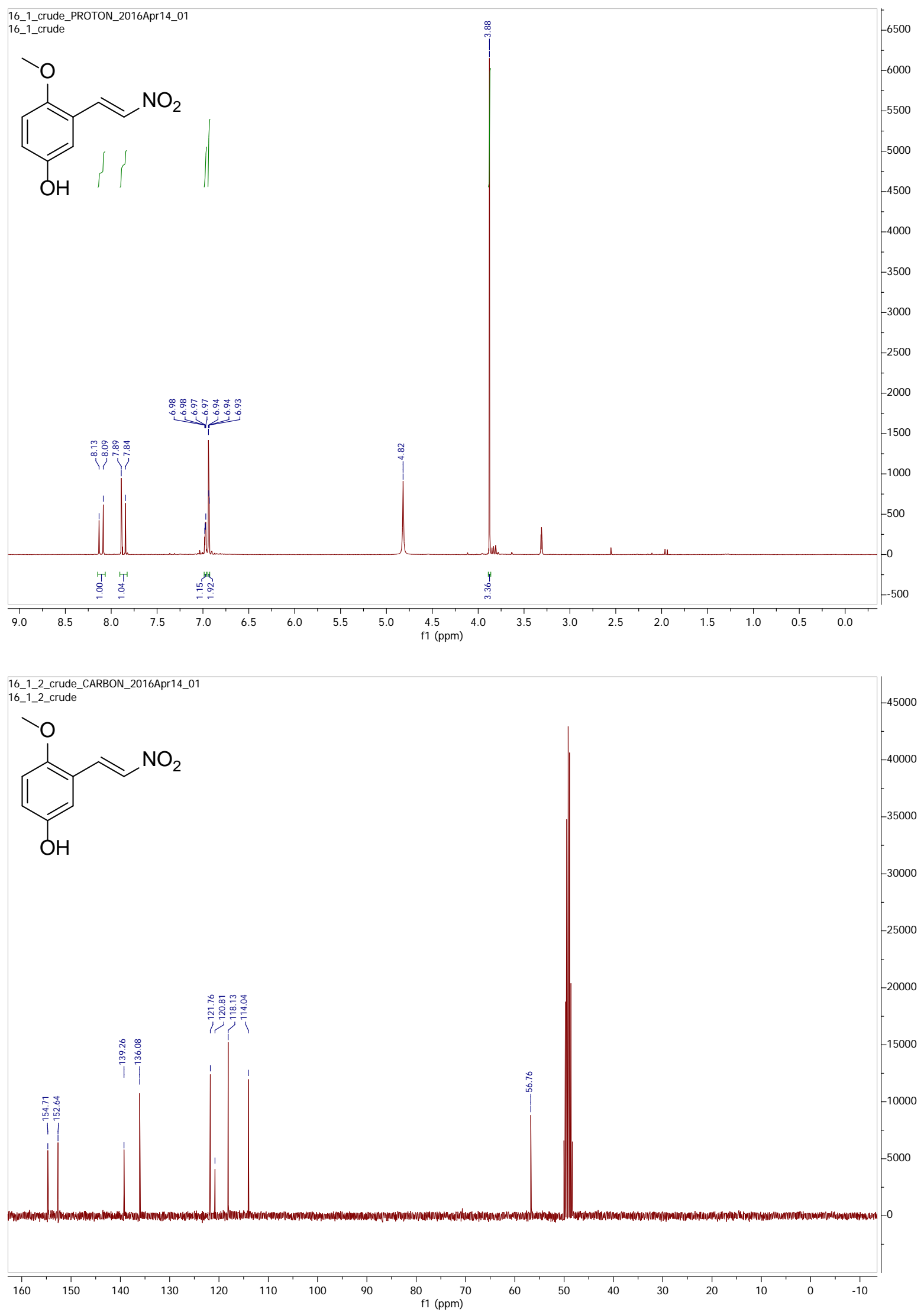
3-(2-aminoethyl)-4-methoxyphenol (4) Solvent: MeOD

9_3_crude_PROTON_2016Apr22_01

9_3_crude

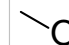
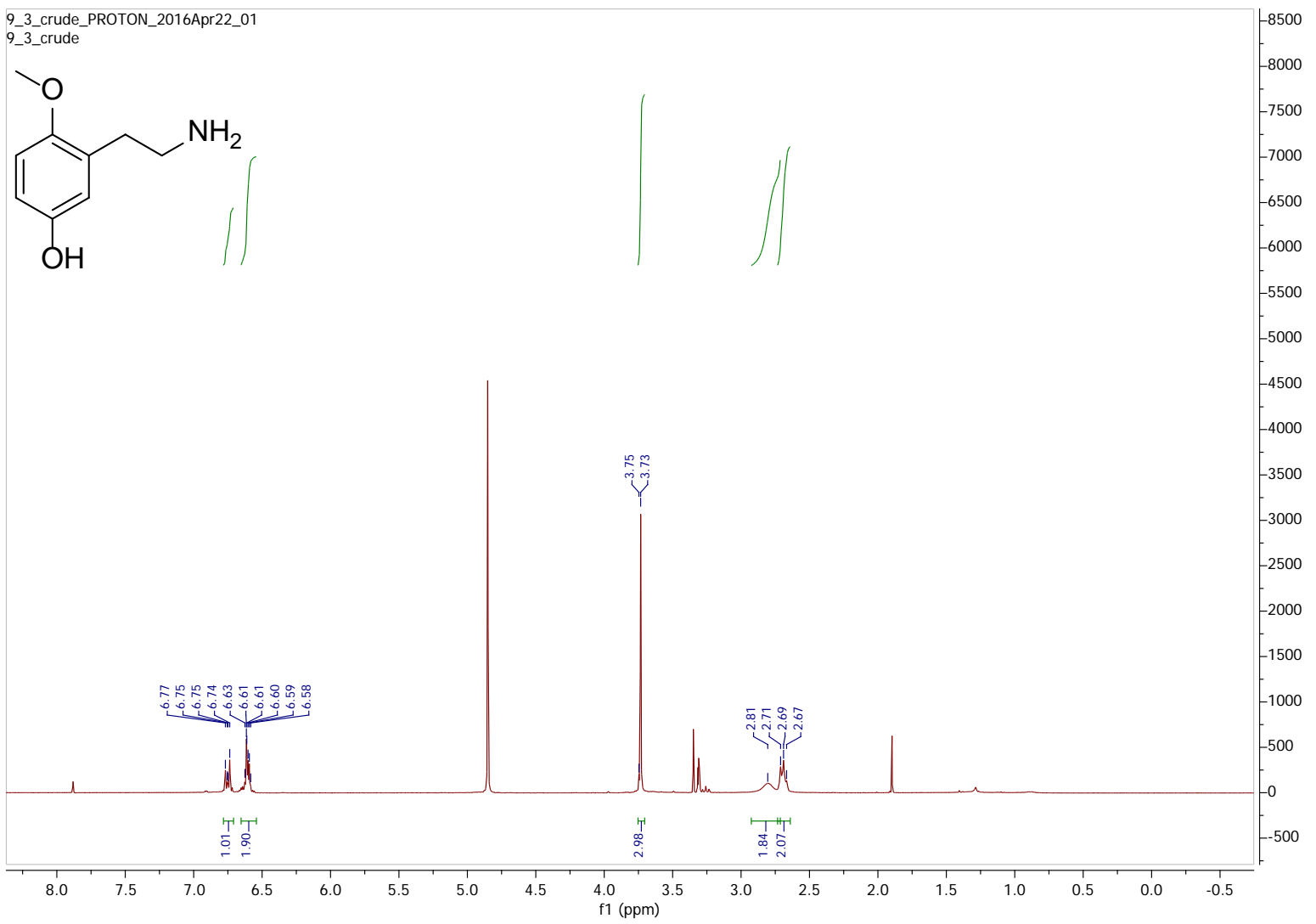

9_3_crude_CARBON_2016Apr22_01 9_3_crude<smiles>COc1ccc(O)cc1CCN</smiles>

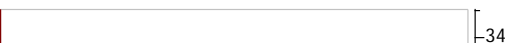



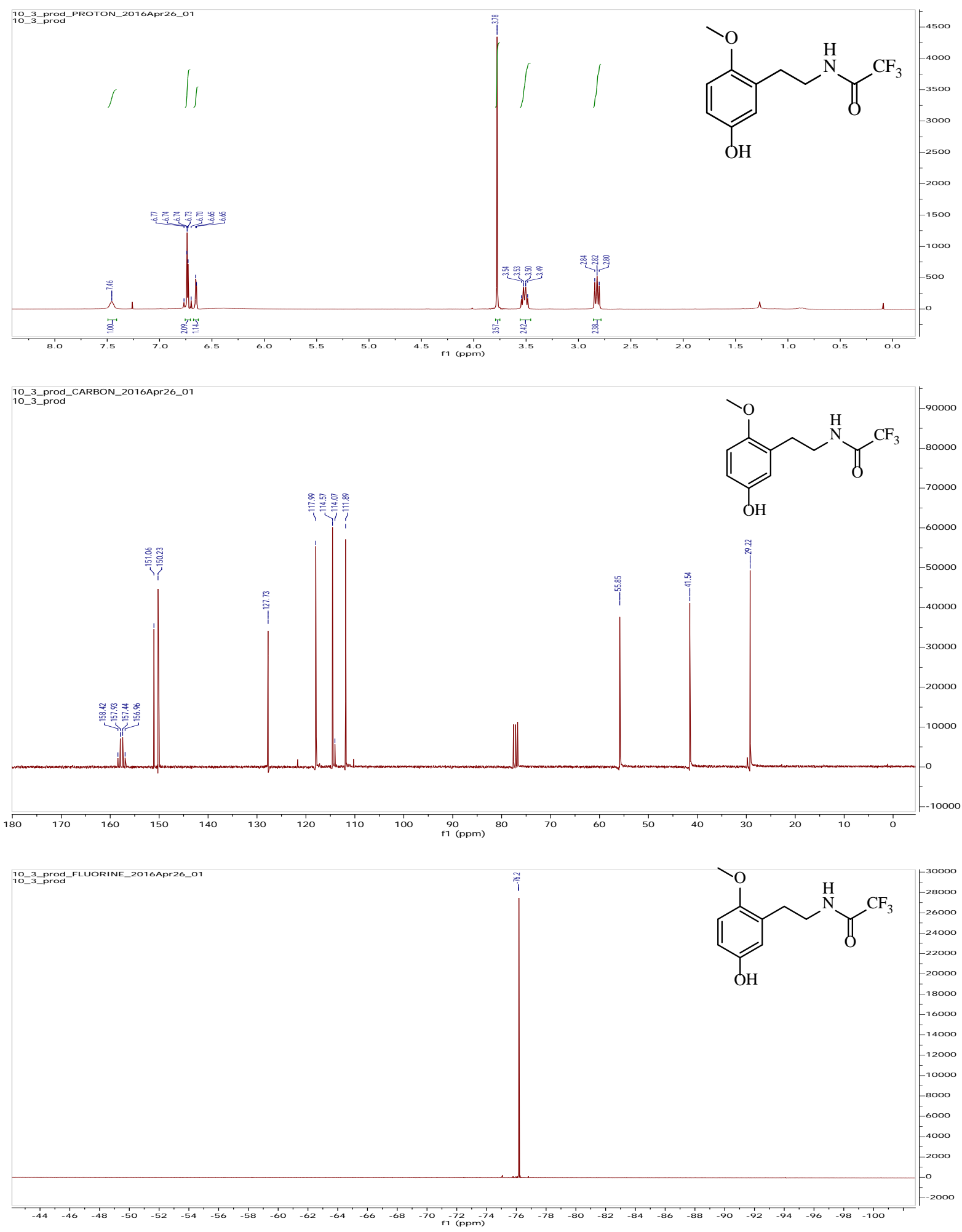


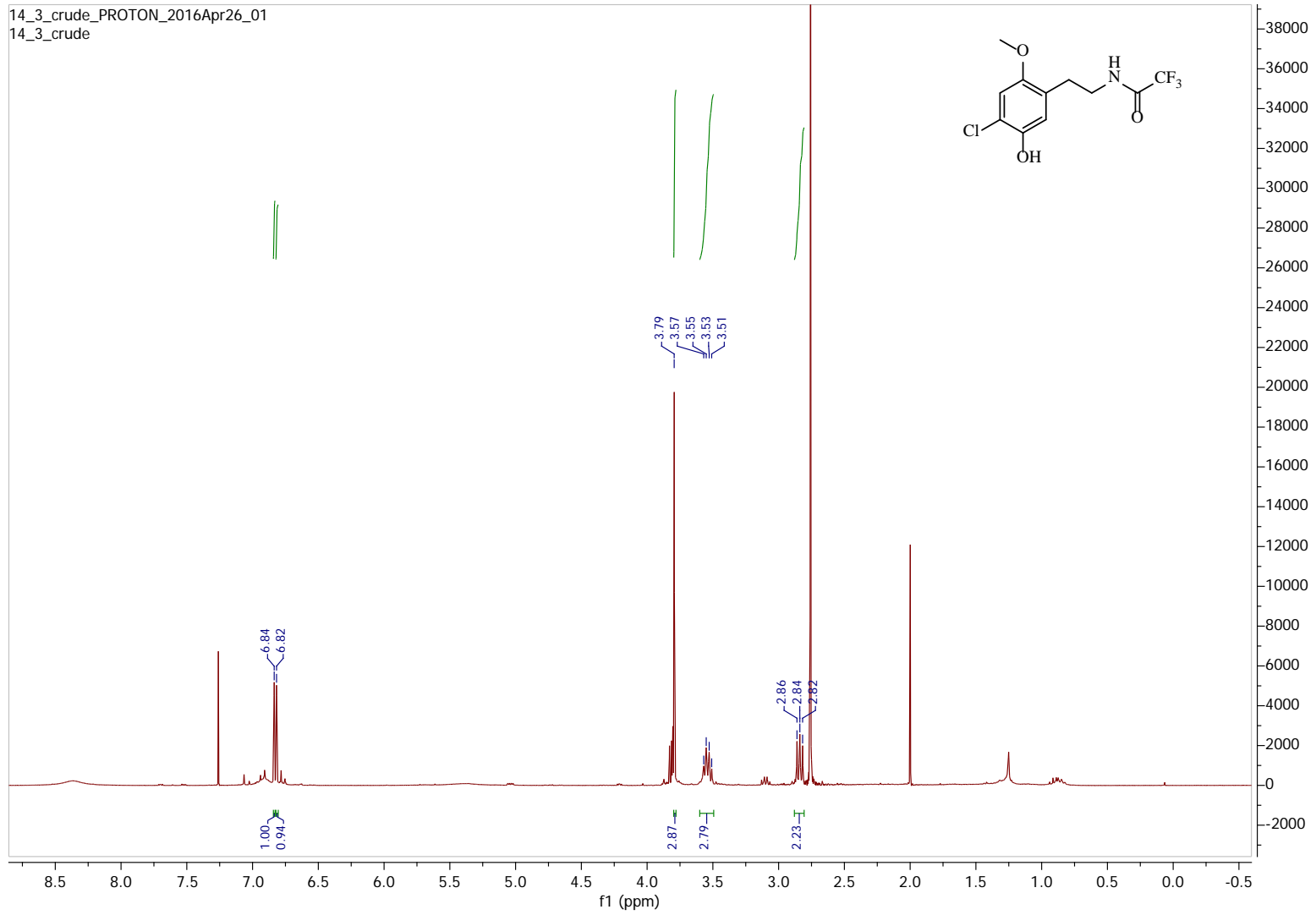




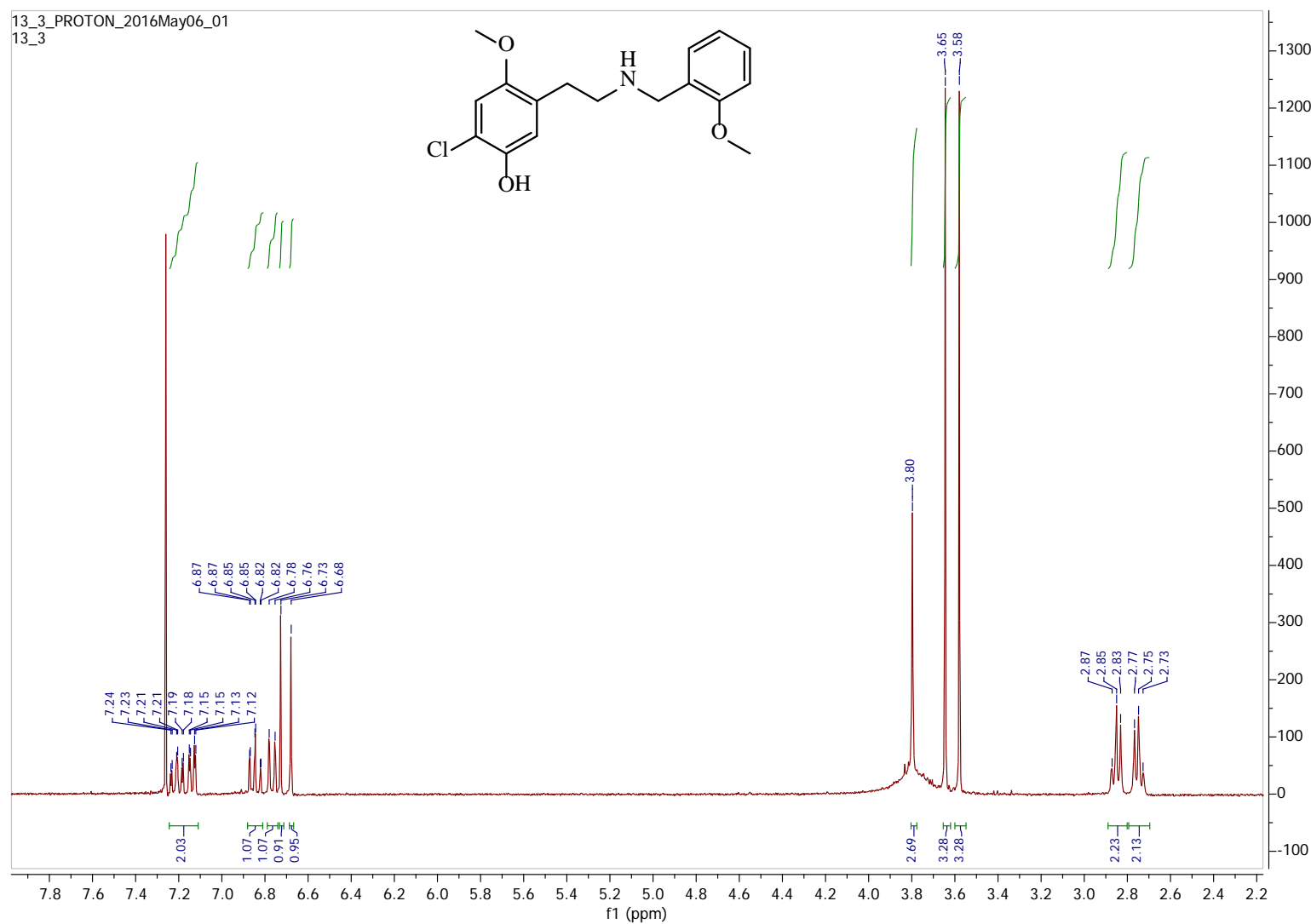

13_3_CARBON_2016May07_01

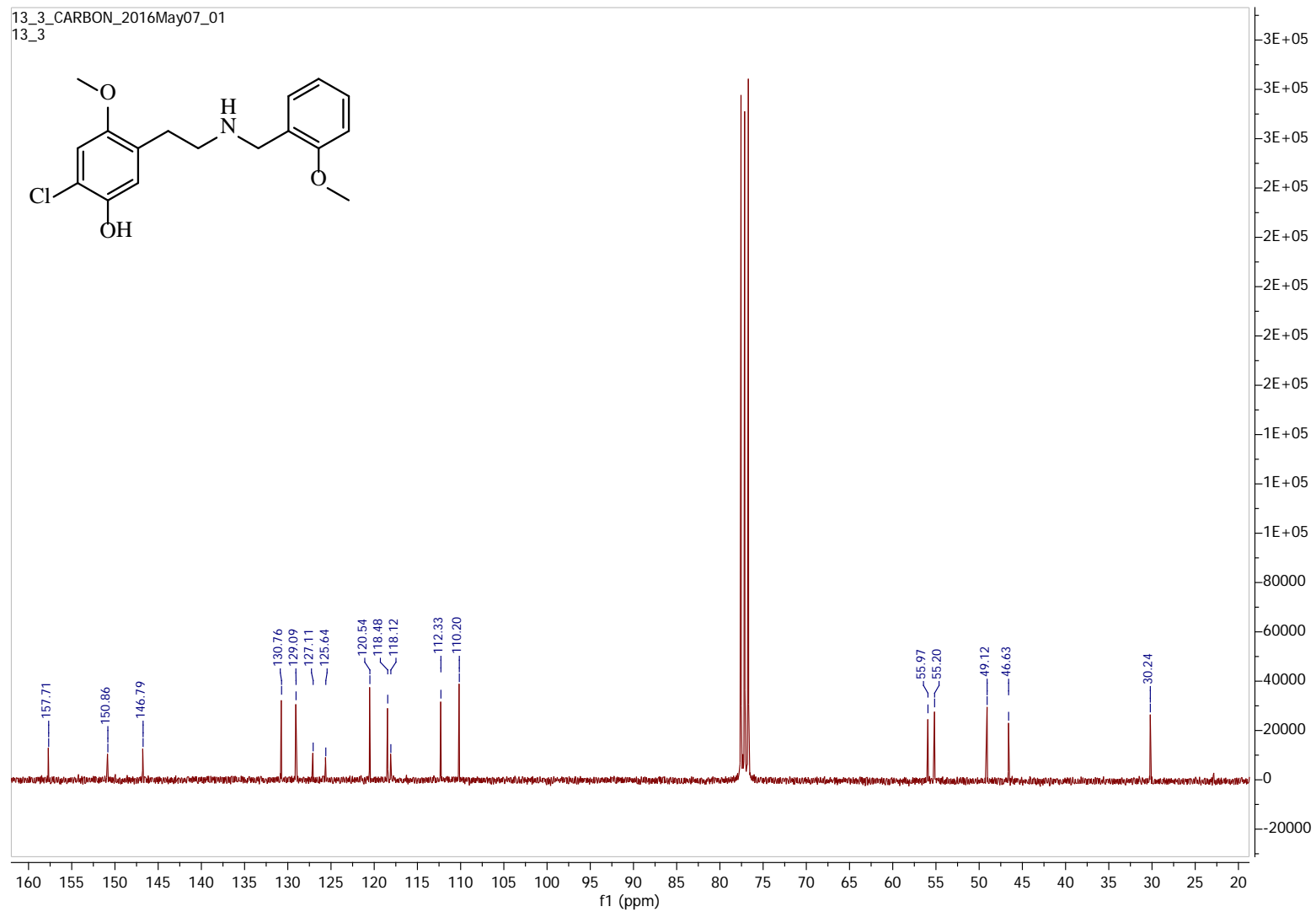



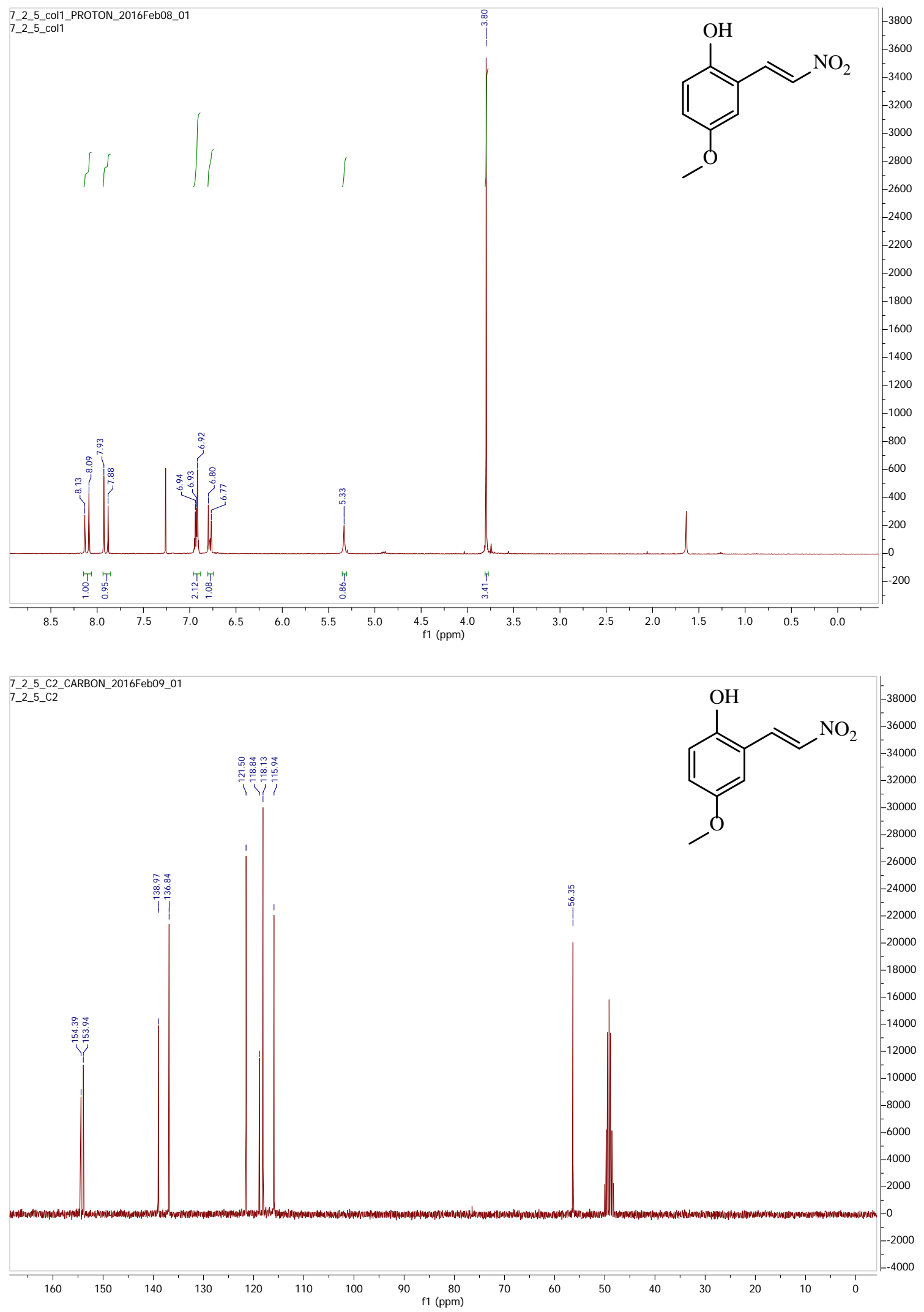

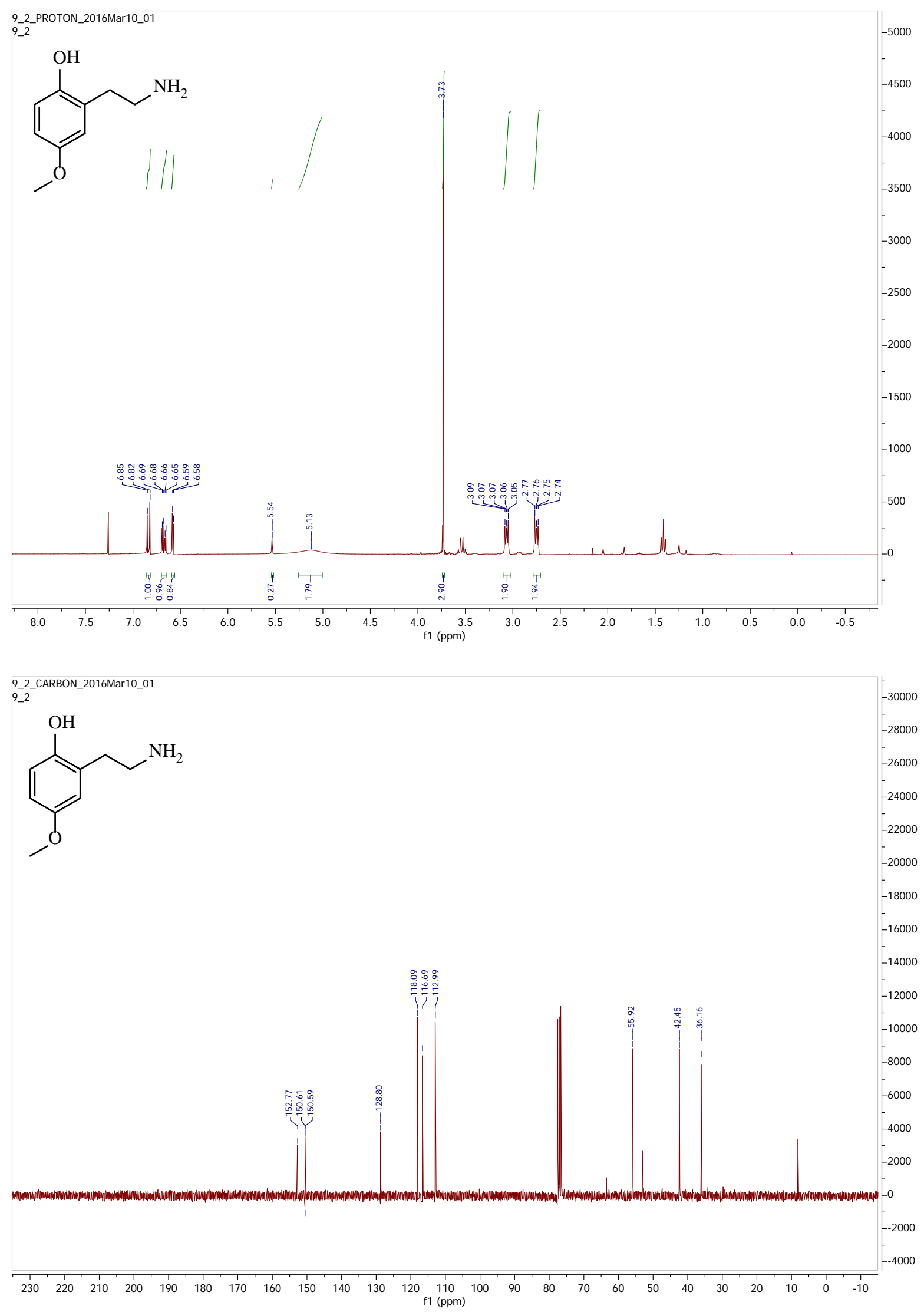

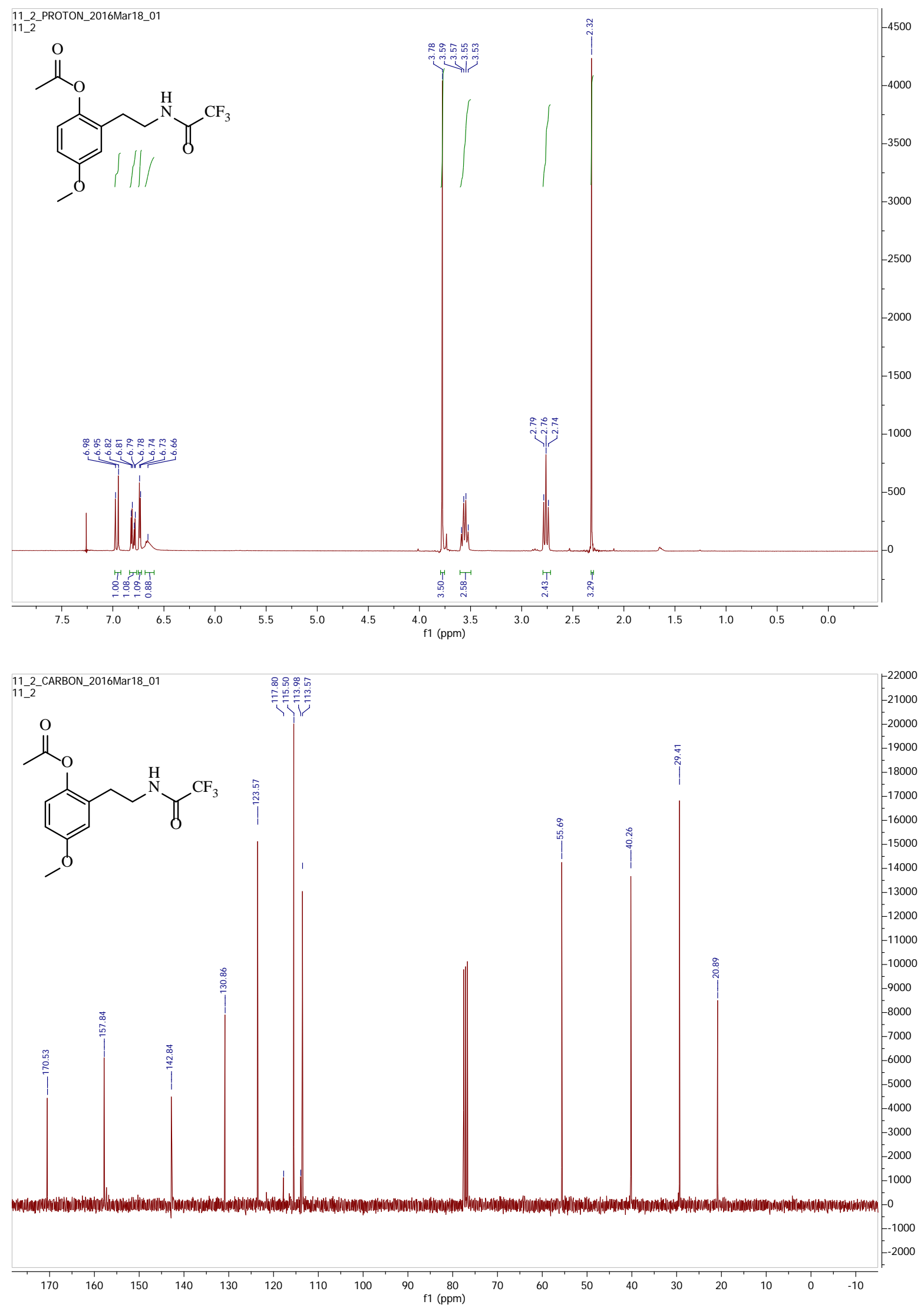
5-chloro-4-methoxy-2-(2-(2,2,2-trifluoroacetamido)ethyl)phenyl acetate (13a) Solvent: $\mathrm{CDCl}_{3}$

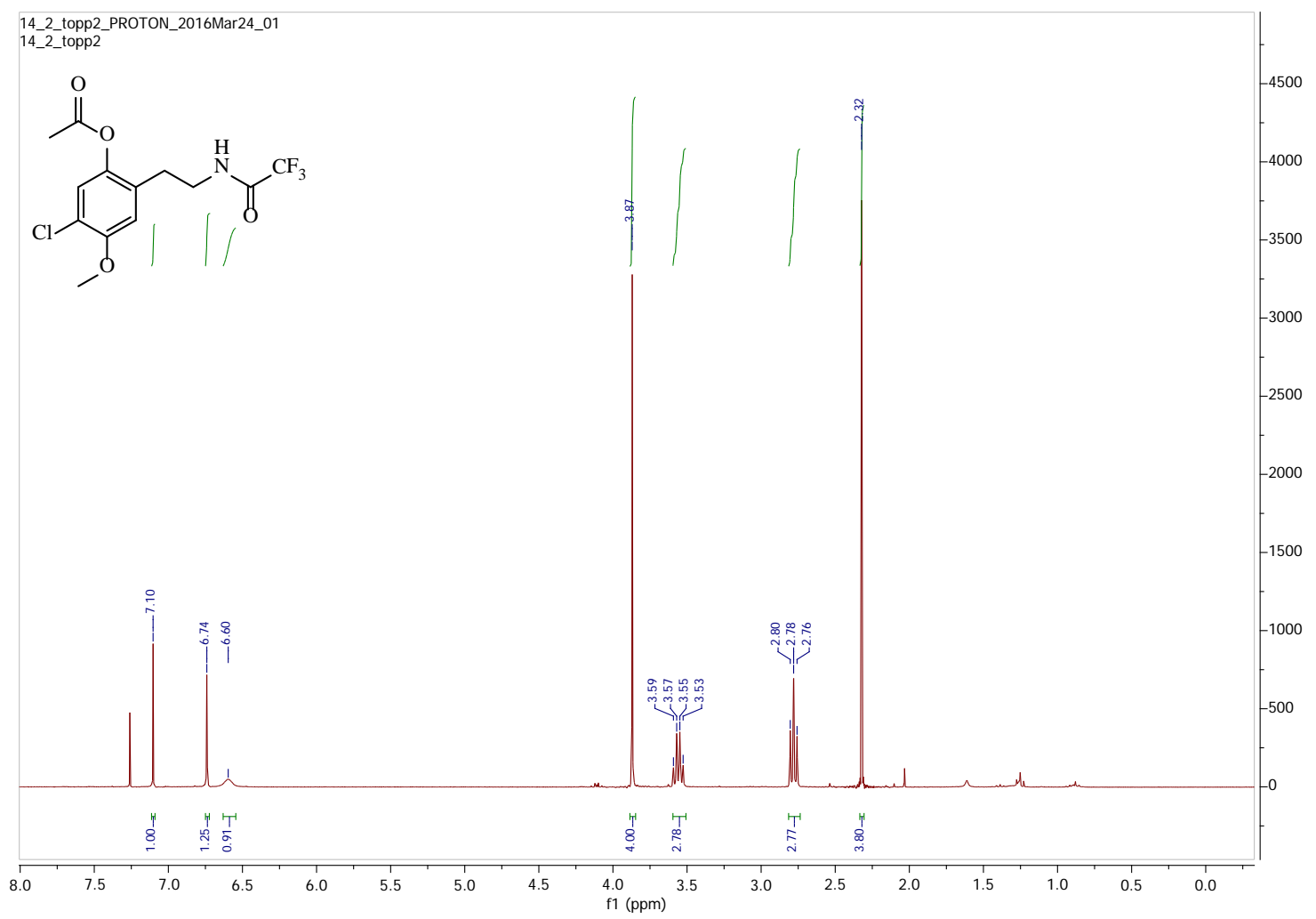<smiles>COc1cc(CCNC(=O)C(F)(F)F)c(OC(C)=O)cc1Cl</smiles> 
5-iodo-4-methoxy-2-(2-(2,2,2-trifluoroacetamido)ethyl)phenyl acetate (13b) Solvent: $\mathrm{CDCl}_{3}$

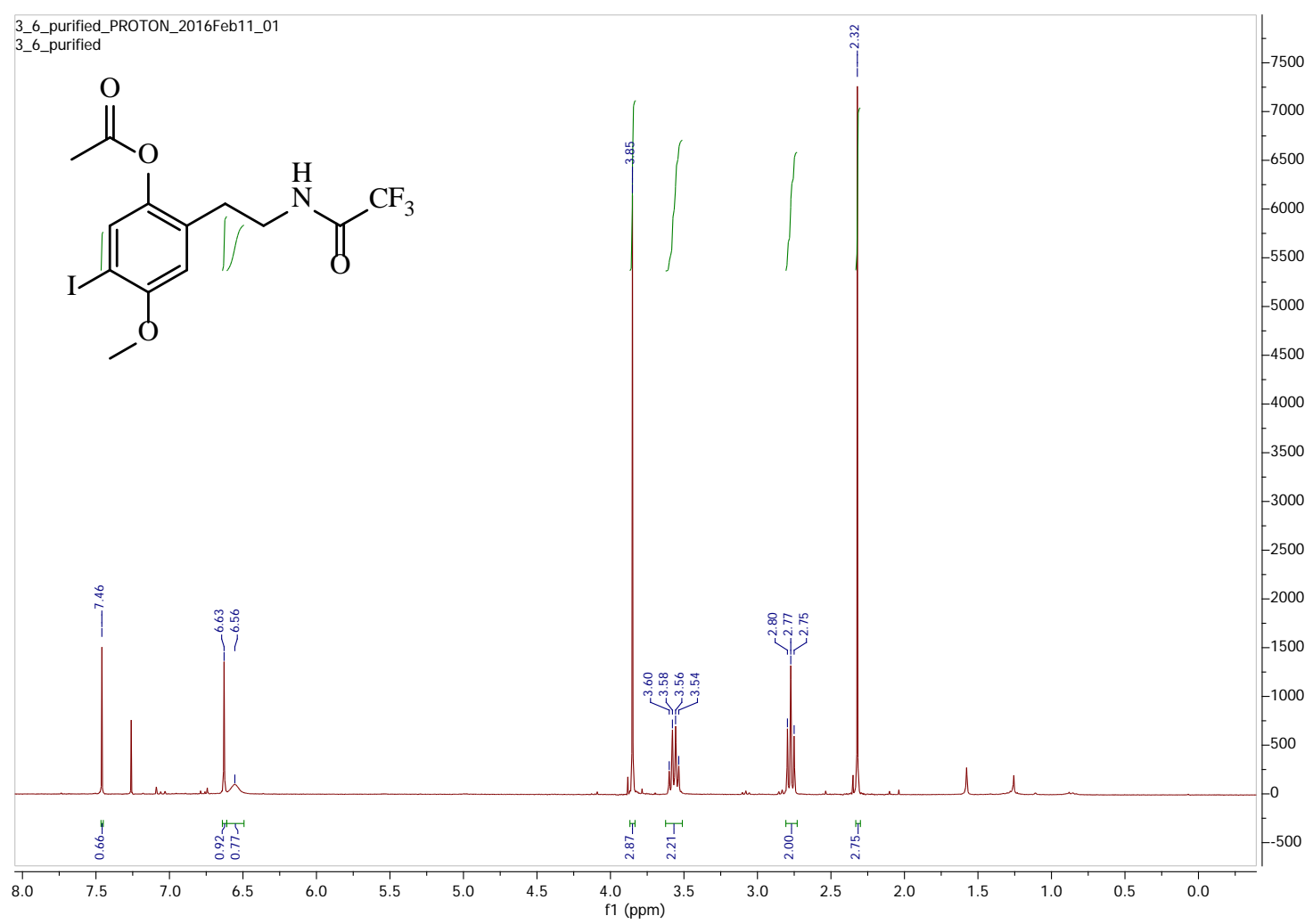


<smiles>COc1cc(CCNCc2ccccc2OC)c(O)cc1Cl</smiles>
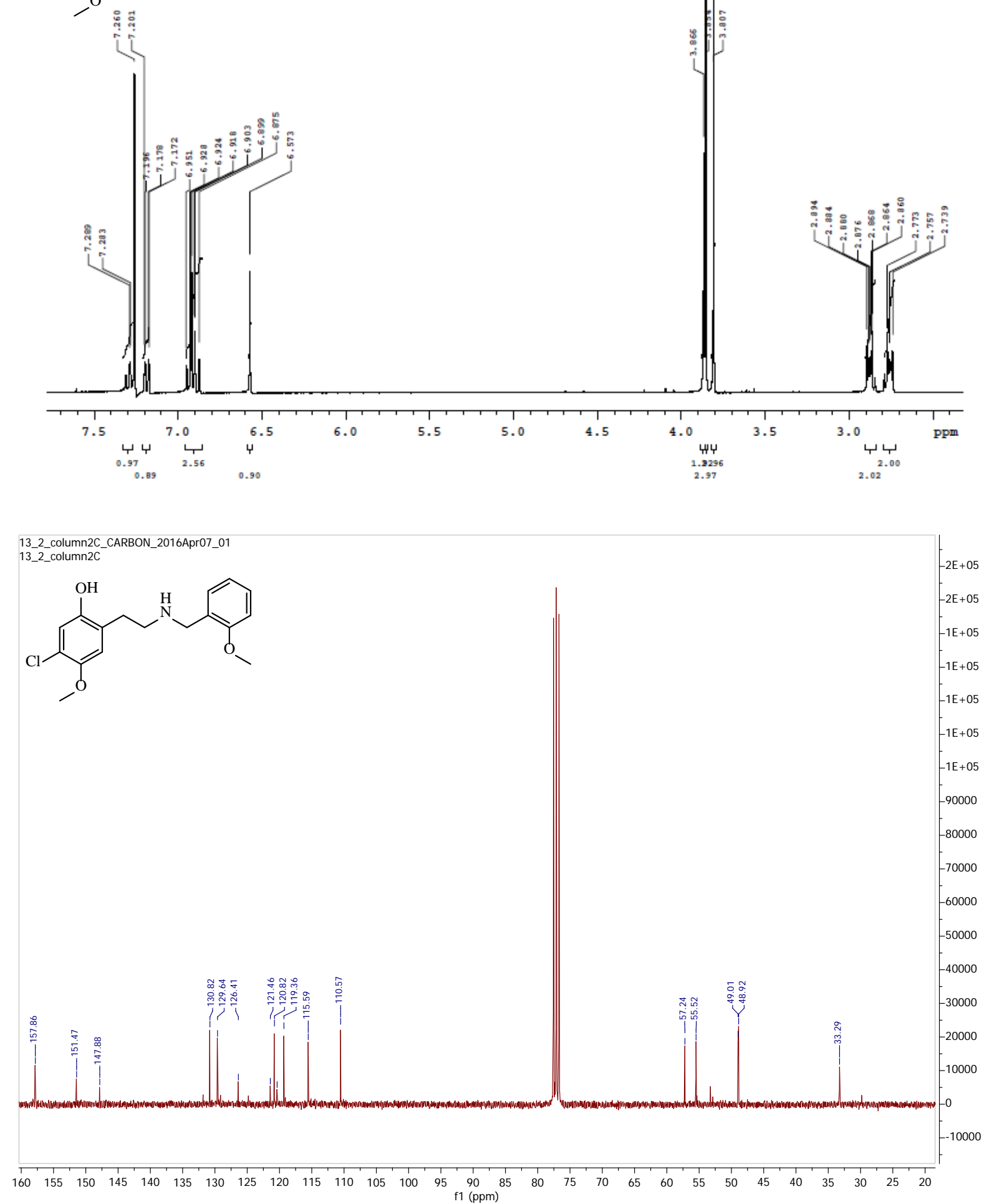

5-iodo-4-methoxy-2-(2-((2-methoxybenzyl)amino)ethyl)phenol (15b) Solvent $\mathrm{CDCl}_{3}$ 

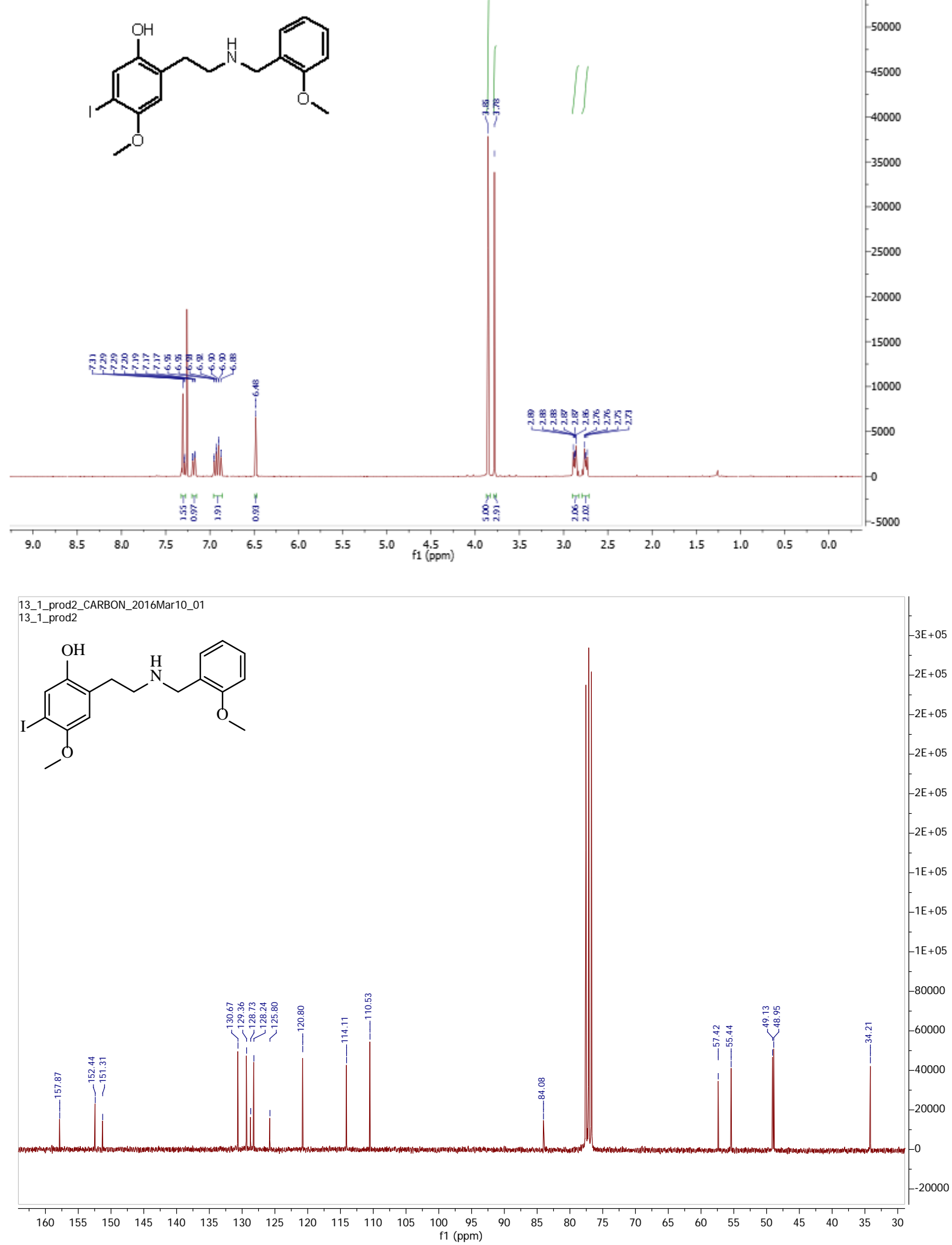

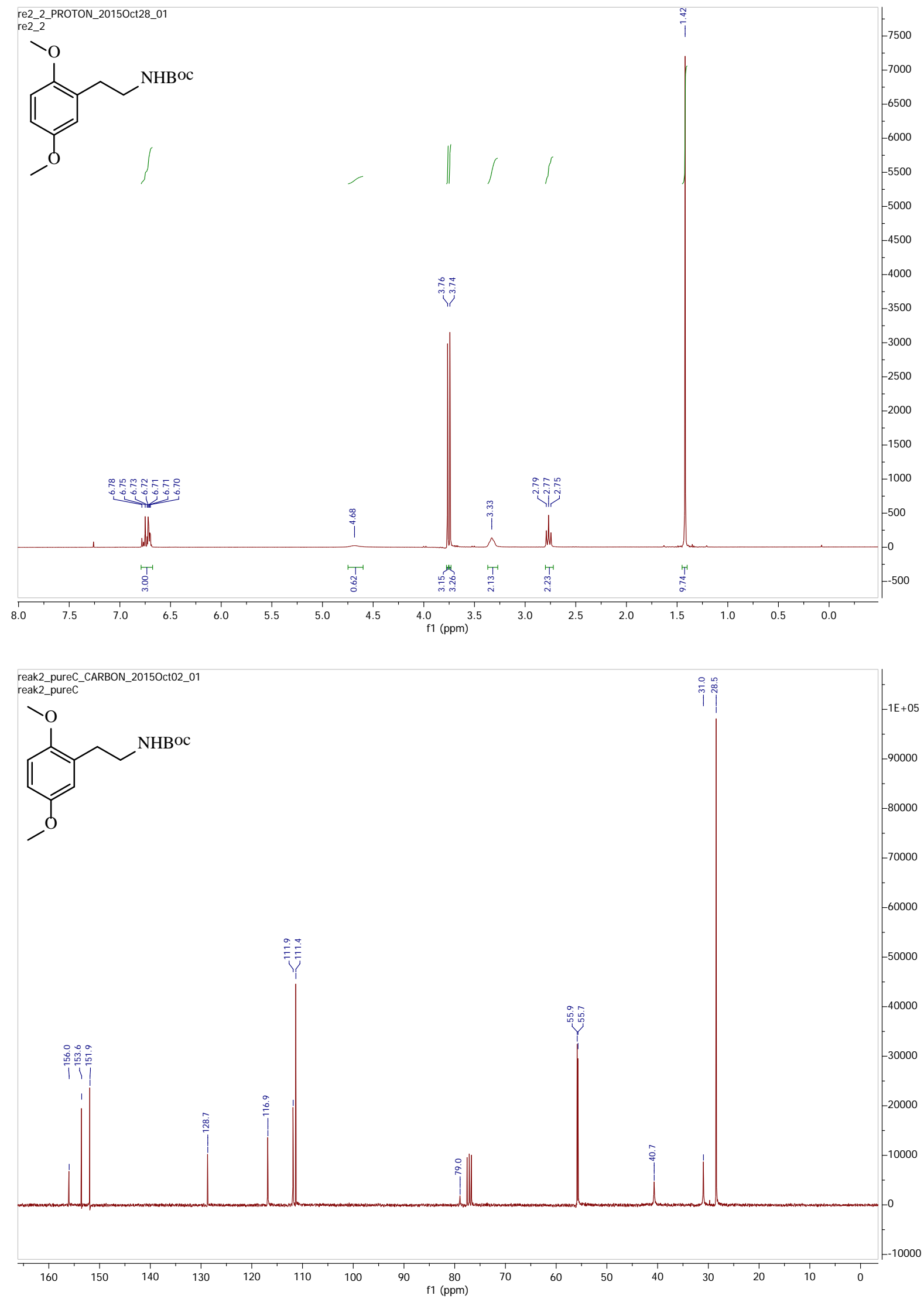

2-(2-((tert-butoxycarbonyl)amino)ethyl)-5-chloro-4-methoxyphenyl acetate (18a) Solvent: $\mathrm{CDCl}_{3}$ 

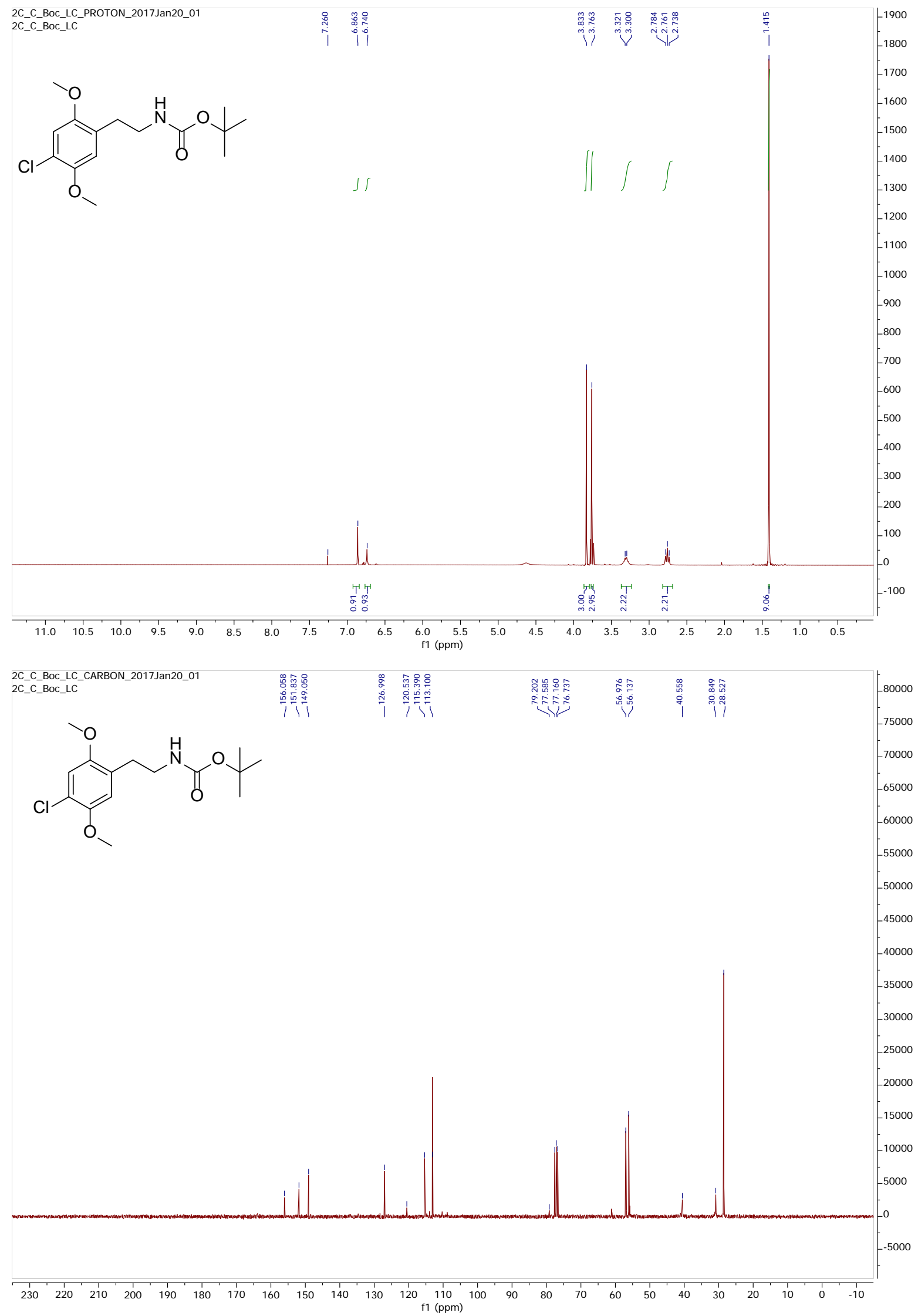

2-(2-((tert-butoxycarbonyl)amino)ethyl)-5-iodo-4-methoxyphenyl acetate (18b) Solvent: $\mathrm{CDCl}_{3}$ 
prod3_3_column3_PROTON_2015Nov06_01 prod3_3_column3
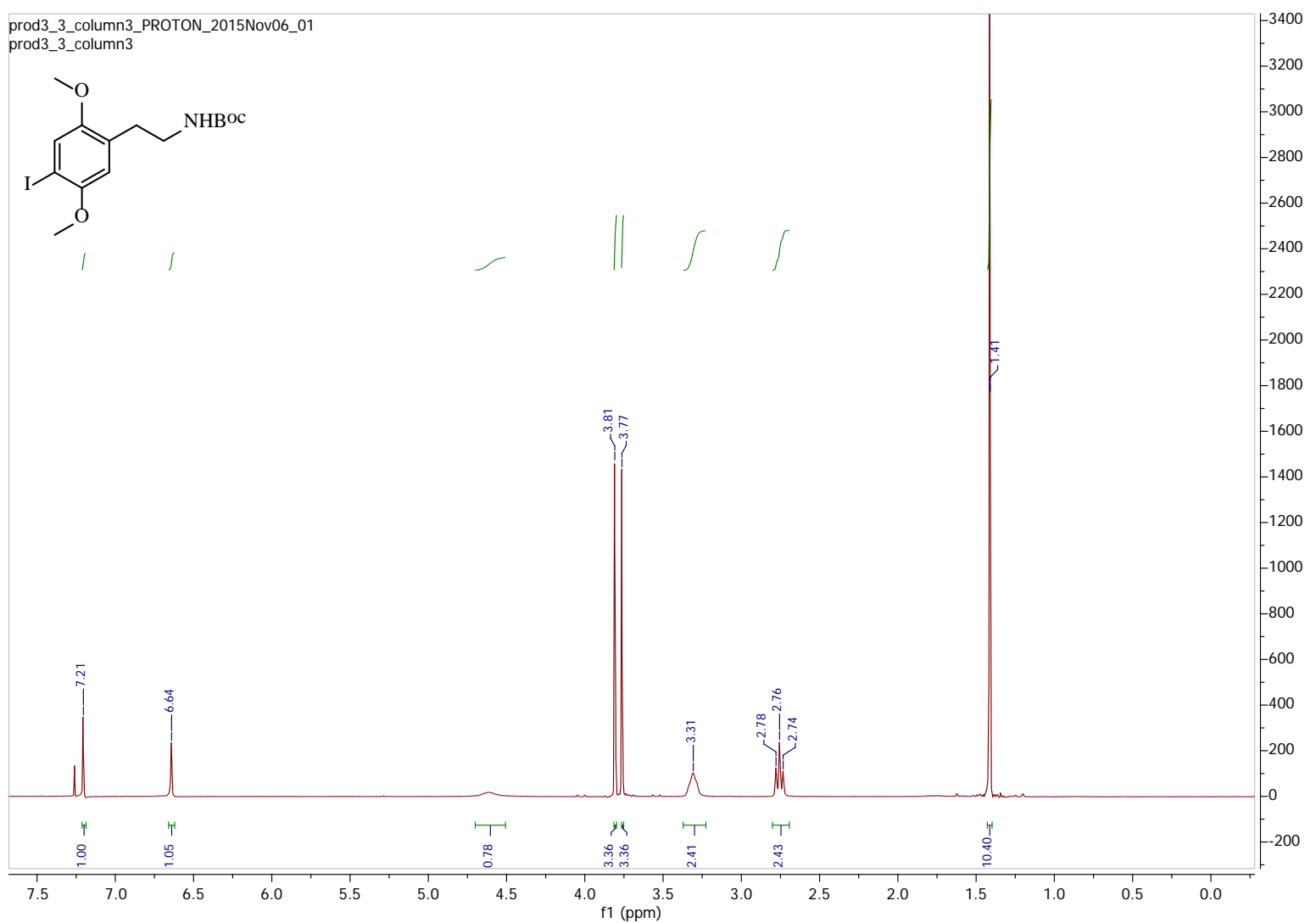

2ci_boc_27_35_CARBON_2015Nov25_01

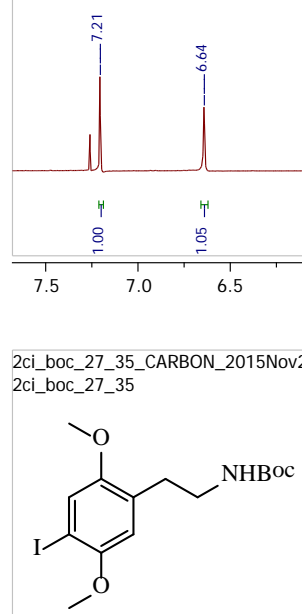

0000 

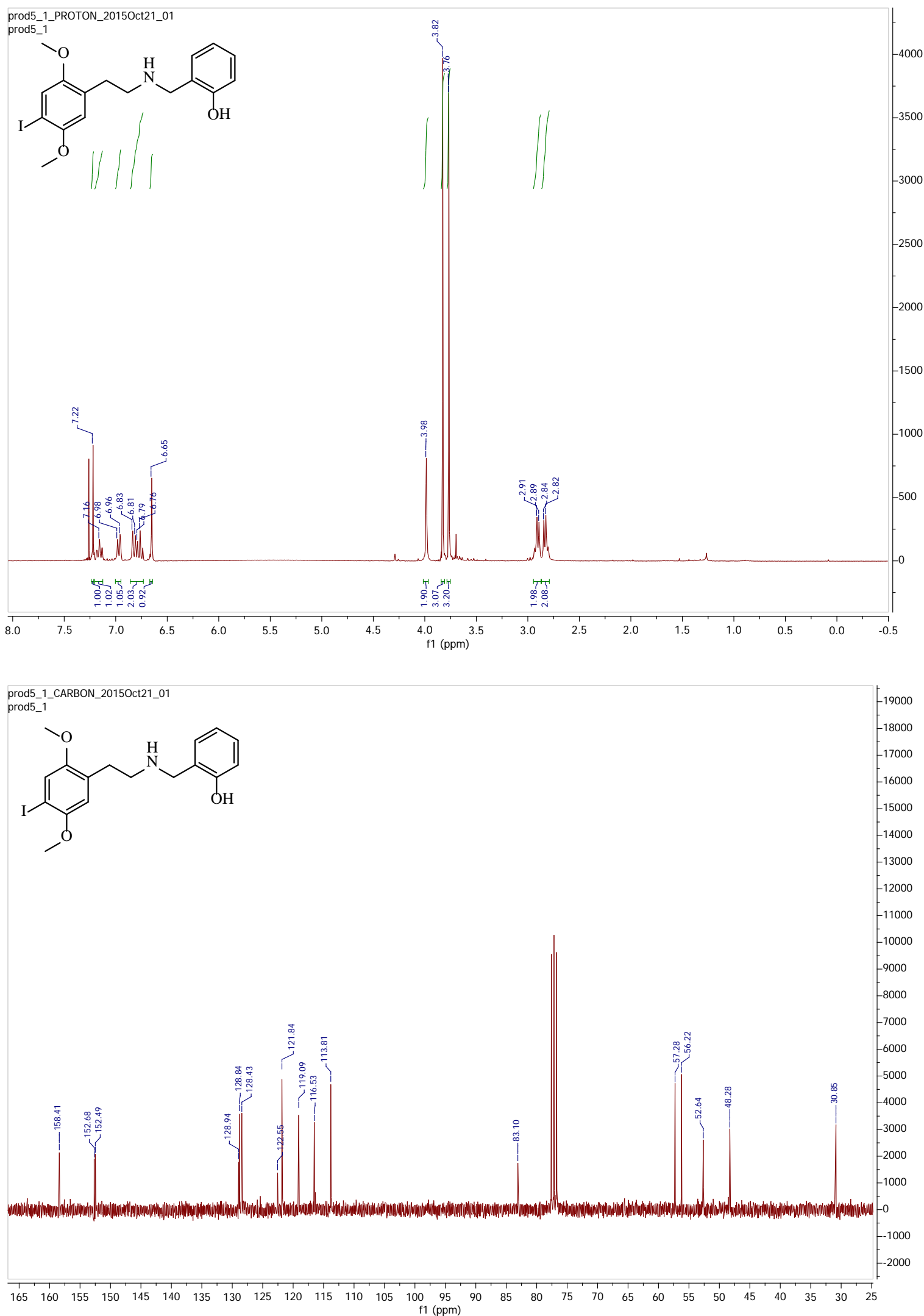

3-(((4-chloro-2,5-dimethoxyphenethyl)amino)methyl)-4-methoxyphenol (20a) Solvent: $\mathrm{CDCl}_{3}$ 


\section{LC sample using freeze-drying}
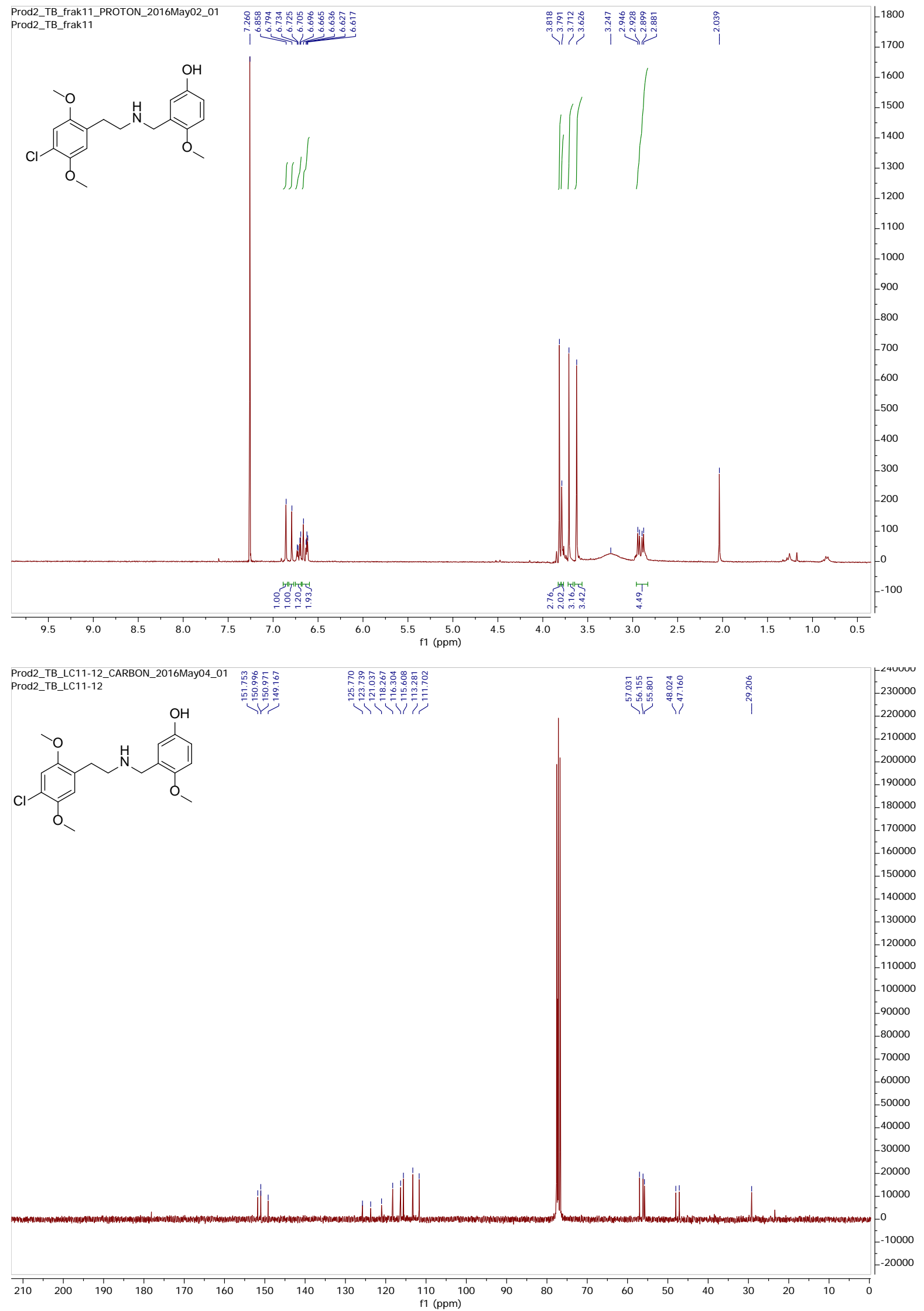

3-(((4-chloro-2,5-dimethoxyphenethyl)amino)methyl)-4-methoxyphenol (20a) Solvent: $\mathrm{CDCl}_{3}$ 


\section{LC sample extracted with DCM}
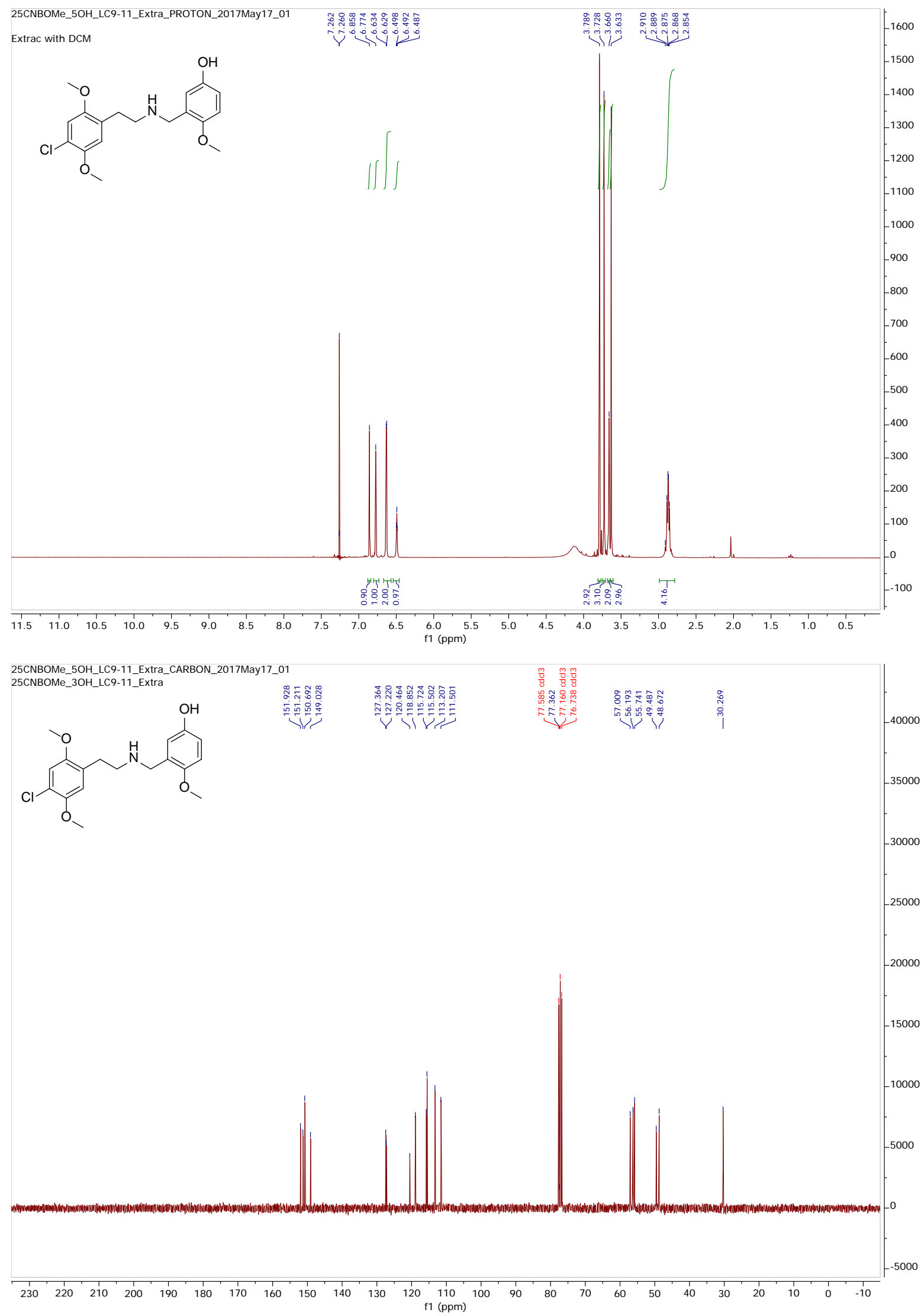

3-(((4-iodo-2,5-dimethoxyphenethyl)amino)methyl)-4-methoxyphenol (20b) Solvent: $\mathrm{CDCl}_{3}$ 


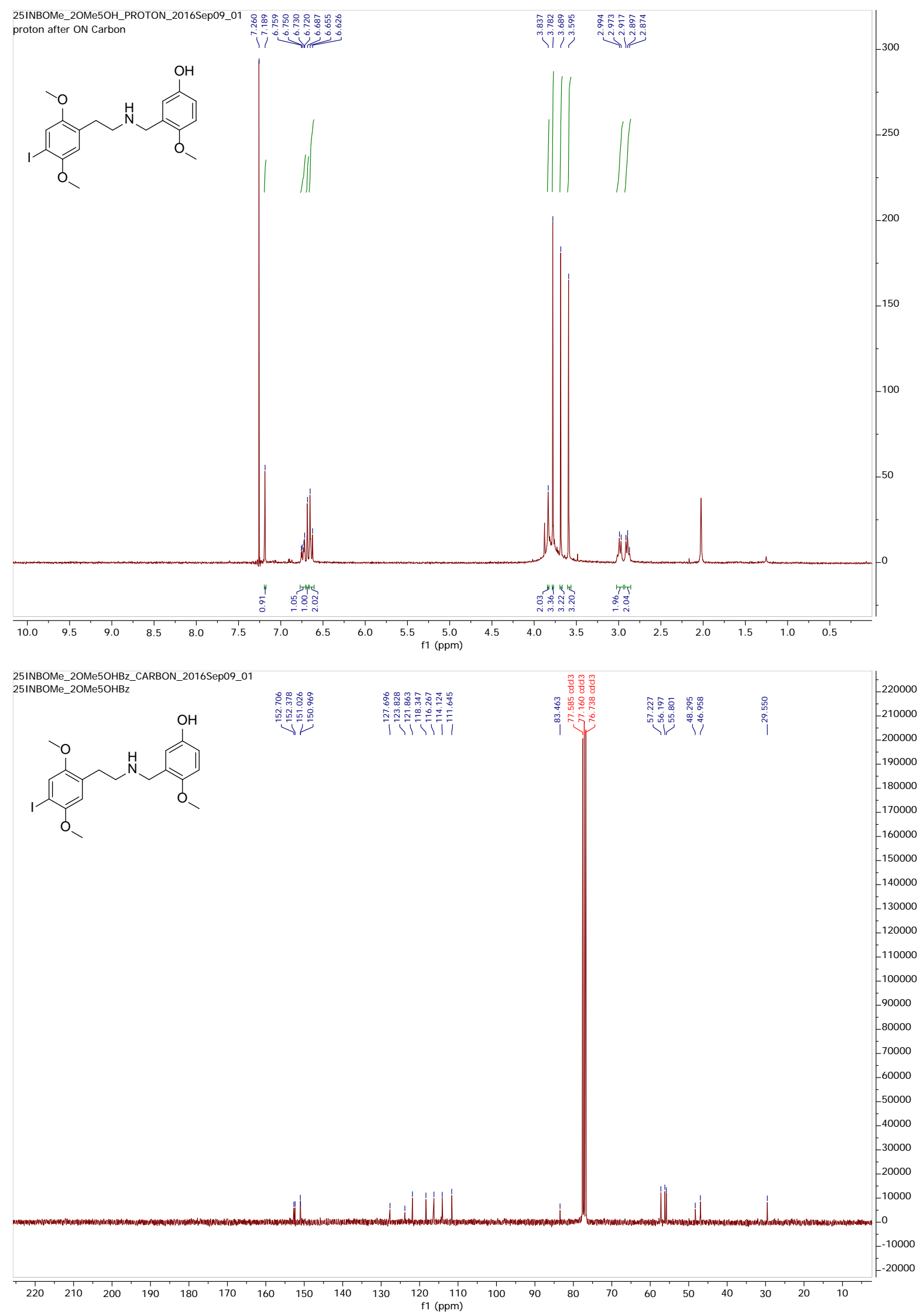

4-(((4-chloro-2,5-dimethoxyphenethyl)amino)methyl)-3-methoxyphenol (21a) Solvent: $\mathrm{CDCl}_{3}$ 

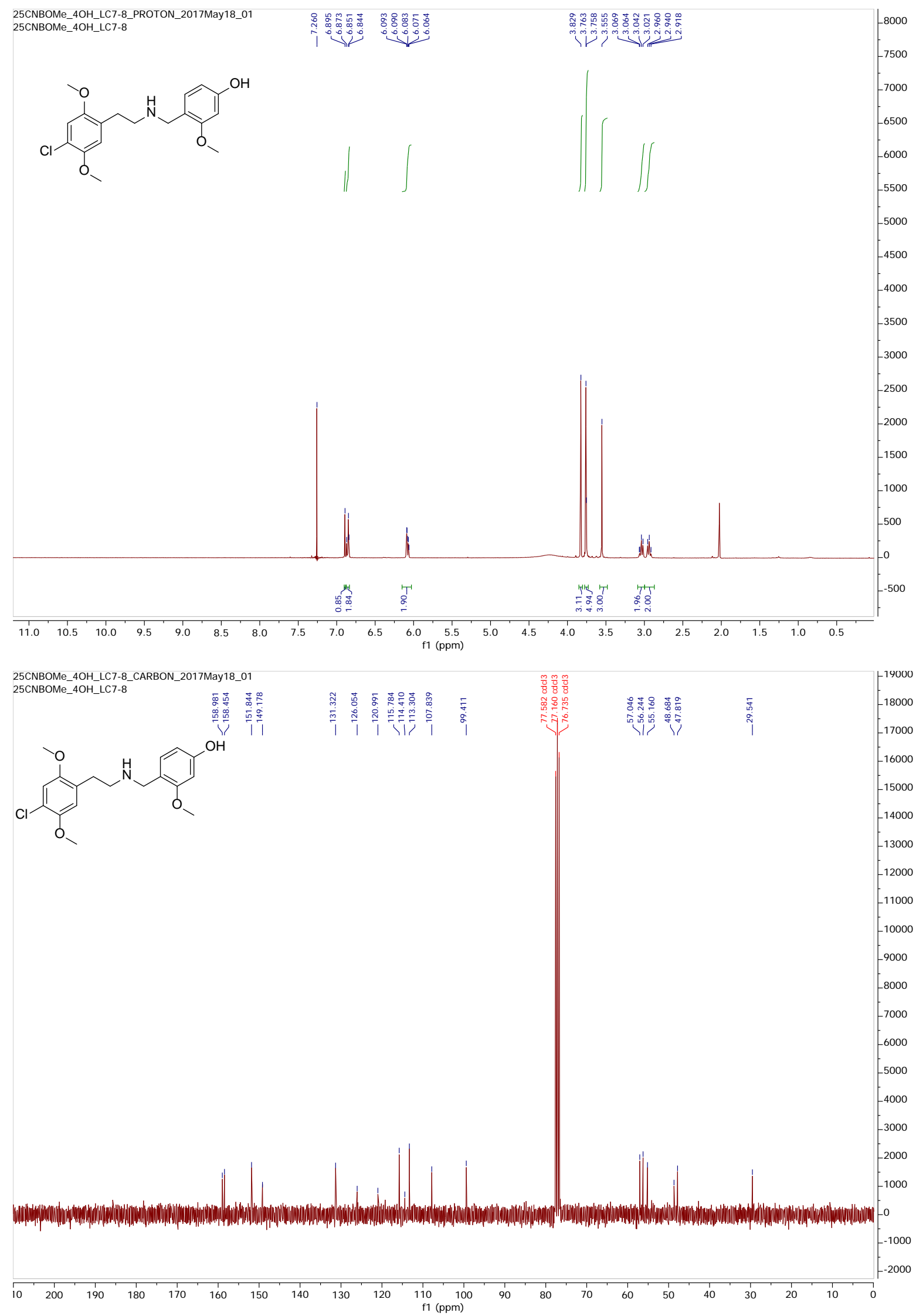

4-(((4-iodo-2,5-dimethoxyphenethyl)amino)methyl)-3-methoxyphenol (21b) Solvent: $\mathrm{CDCl}_{3}$ 

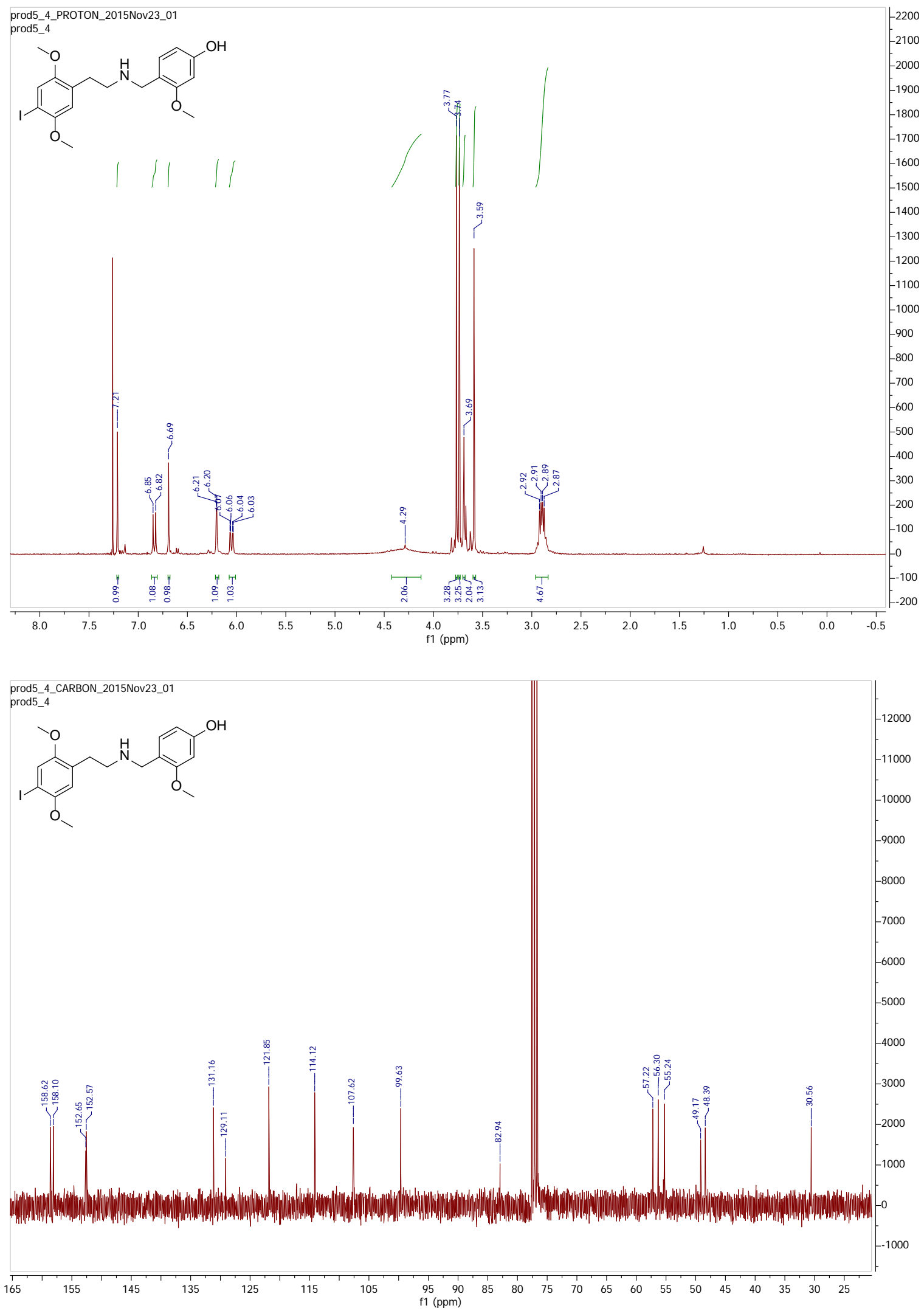
3-(((4-chloro-2,5-dimethoxyphenethyl)amino)methyl)-2-methoxyphenol (22) Solvent: $\mathrm{CDCl}_{3}$
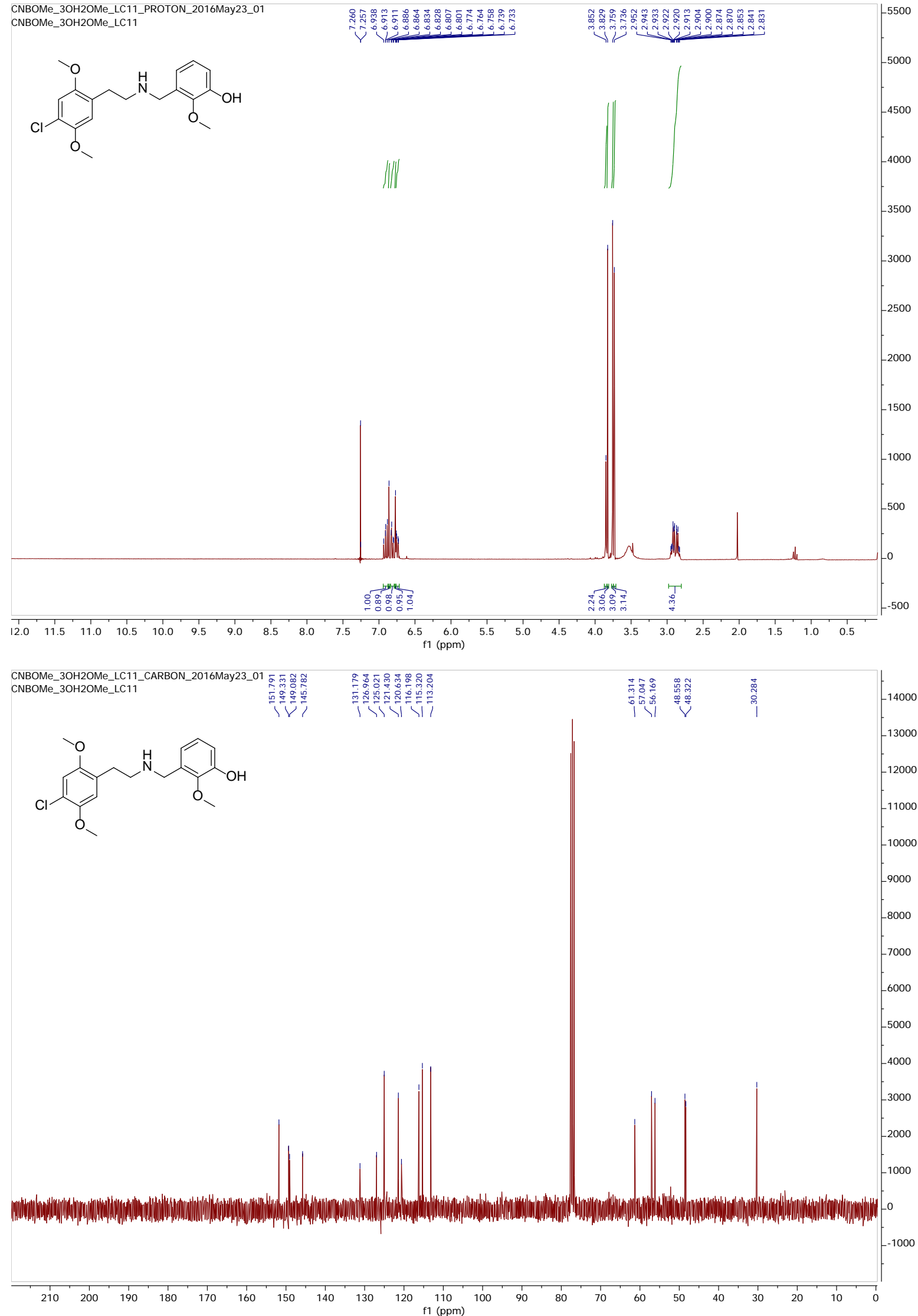
2-(((4-chloro-2,5-dimethoxyphenethyl)amino)methyl)-3-methoxyphenol (23) Solvent: $\mathrm{CDCl}_{3}$
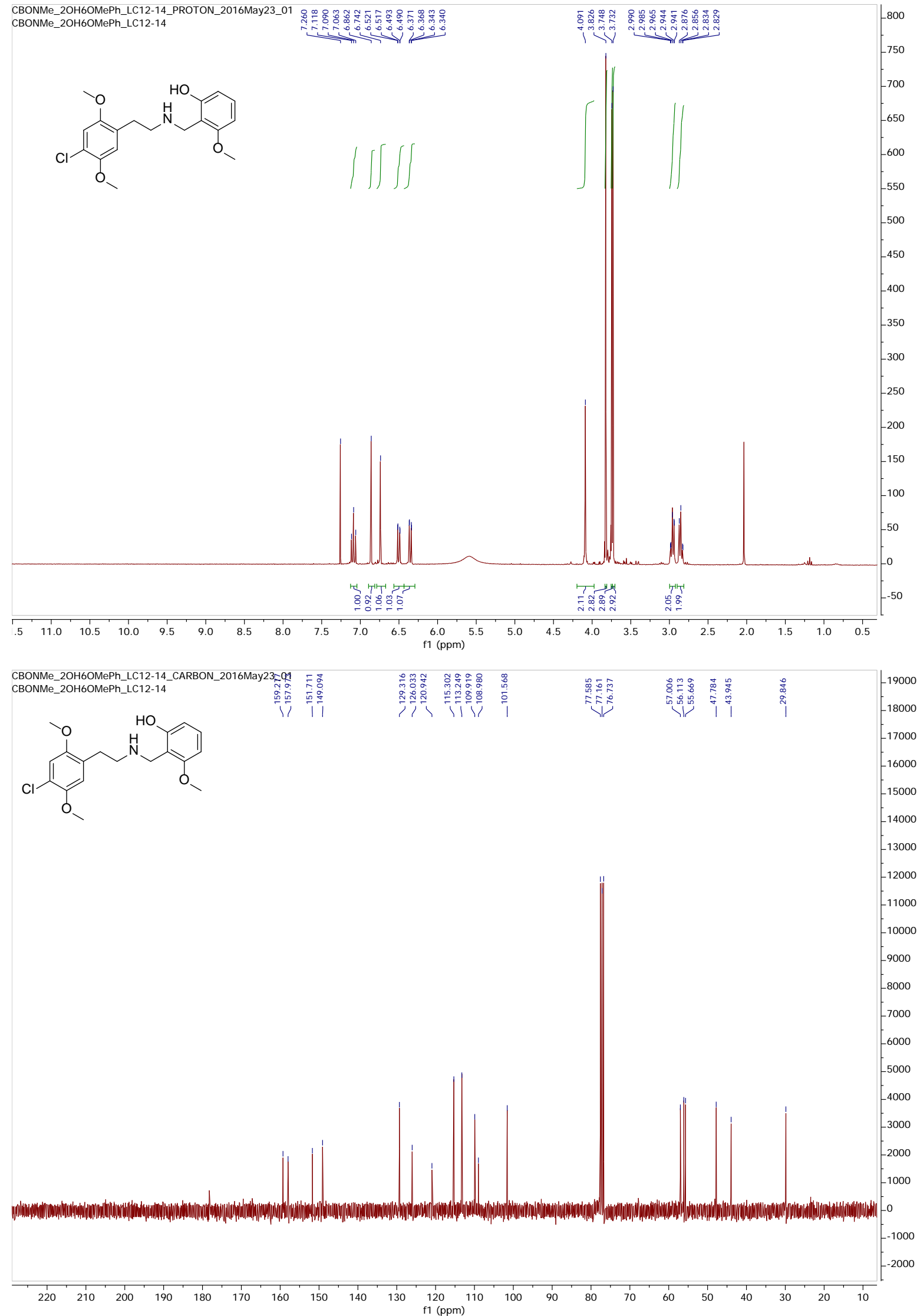